\title{
THE DETERMINANTS OF THE STRUCTURE OF RAINY DAY FUNDS*
}

\author{
Isabel Rodriguez-Tejedo ${ }^{\dagger}$
}

May 2008

Department of Economics

University of Navarra, Pamplona

\begin{abstract}
This paper investigates the factors that determine the configuration of rainy day funds along their two most important dimensions, deposit and withdrawal requirements. Most states in the United States have created budget stabilization funds (or rainy day funds) to accumulate savings that would allow them to reduce the impact of adverse fiscal conditions. However, it has been shown that the effectiveness of these funds greatly depends on their institutional structure and that most states choose configurations that compromise the efficacy of the fund. Using multinomial discrete techniques, and introducing for the first time the ordered nature of the requirements in the analysis, our results indicate that political and institutional factors, like political fragmentation and some strict fiscal institutions are associated with weak (less effective) budget stabilization funds, while some economic factors -such as the volatility of state tax revenues- are associated with stricter funds.
\end{abstract}

I would like to thank Wallace E. Oates, John Wallis, Robert Schwab and Yyannú Cruz-Aguayo for their helpful comments and suggestions. All remaining errors are my own.

†Email address: isabelrt@unav.es 


\section{Introduction.}

State legislatures have constrained themselves through history to prevent the functioning of a democratic system from negatively affecting finances in the presence of an ever changing and, to some extent, unpredictable environment. ${ }^{1}$ Examples of these self-imposed constraints can be found in the limits and rules imposed on state budgets, such as balanced budget provisions, tax and expenditure limitations, debt restrictions, etc. These rules are aimed at preventing politicians from starting projects and incurring excessive expenditures -whose consequences would become evident later, when the officials may no longer be in office. However, they also diminish the state's ability to deal with crises, ${ }^{2}$ a problem that is aggravated due to the fact that state finances tend to be pro-cyclical: in times of prosperity, states receive moneys from expanded tax bases, and the number of people who qualify for state assistance diminishes. Conversely, when the economy is in recession, revenues fall while spending needs increase.

Budget stabilization funds (BSFs henceforth), also known as rainy day funds (RDFs), are a relatively new addition to the set of tools states have at their disposal to face the fiscal pressures brought about by business cycles. BSFs can help states smooth their consumption by serving as receptacles for savings to be used in times of economic distress. As Poterba (1995) points out in his study of the real effects of capital budgets in the states "since...fiscal institutions have important effects on policy outcomes, it is important to understand the factors that lead to changes in these institutions ${ }^{3}$." This is true of RDFs, since their structure, in terms of the rules that control the deposit and withdrawal of funds from the fund, has important consequences for their effectiveness. ${ }^{4}$ The choices states make regarding the configuration of their BSFs are, therefore, not innocuous. Despite its relevance, the literature has so far overlooked the factors that determine the adoption of a particular set of regulations for state BSFs. We use a categorization based on the stringency of the rules that dictate how funds in

${ }^{1}$ Wallis (2005) presents the case of states constraining themselves not to undertake large projects without a sound plan for repayment, as a consequence of the experience with canal and railroad construction, where failed projects imposed a heavy burden on states.

${ }^{2}$ Lowry and Alt (2001) note that there are costs associated with adjusting a budget and it is impossible to guarantee that the benefits from fiscal discipline will compensate for the loss of flexibility in state policy that comes with reducing the state's ability to run deficits. 3 pp 185.

${ }^{4}$ Sobel and Holcombe (1996), Douglas and Gaddie (2002), Zahradnik and Ribeiro (2003). 
the RDF enter and leave the fund to analyze why some states adopt very demanding RDFs in terms of the rules for deposit and withdrawal, while others prefer more relaxed regulations.

Using multinomial and ordered econometric methods, we analyze the effect of various economic, political and institutional factors in the RDF configuration decisions of the states. With this method, we find that states with larger Senates are more likely to adopt weak rules, and higher levels of fragmentation in the lower House reduce the odds of adopting strict requirements. Also, states with appointed supreme courts are more likely to establish demanding rules, as are states whose RDFs are constitutional in nature. Finally, we find evidence that states with higher volatility in their tax income or that exert more tax effort are more likely to establish strict RDFs.

RDFs are just one of the tools states have at their disposal to reduce the negative effects of economic downturns, but their importance becomes apparent once we examine the alternatives closely. R. Holcombe and R. Sobel (1997) conclude that cyclical variability of state revenues (as opposed to expenses) takes the larger share in the responsibility for state government financial crises. Their analysis indicates that there is no simple recipe to reduce revenue variability, and they propose that states concentrate instead on smoothing their resources over the business cycle. The set of tools available for state consumption smoothing is, however, more reduced than its household counterpart. The same institutions that are meant to stimulate responsible fiscal behavior restrict the usage of debt for business cycle smoothing, ${ }^{5}$ leaving four main options open to state officials: increasing taxes to match spending needs, reducing spending in accordance with the decrease in means, using fiscal gimmicks, and depleting previously stored resources. ${ }^{6}$ The use of moneys from BSFs falls in this last category. Before describing these funds in detail, we briefly review the reasons that make the other policy venues unattractive or unsatisfactory to fully solve the financial problems states face during crises.

\footnotetext{
${ }^{5}$ States do borrow (see Brecher et al (2003)), but it is rare to find states that use long-term rate debt to finance current expenses (Snell (2004)). For a more in-depth review of debt limits and their impact on state economies the reader is referred to Rodriguez-Tejedo (2006).

${ }^{6}$ McGranahan (2002) in her analysis of the 2001 crises analyzes "the combination of cyclical revenues with acyclical or even counter cyclical obligations and institutions that are not permitted to use financial markets to deal with this disjoint", pp 20.
} 
Holtz-Eakin, Rosen and Tuller (1994), using data on aggregate local and state expenditure, find that nearly all expenditure is driven by current resources. In this spirit, the first of the four solutions mentioned above calls for increases in taxes to meet spending demands. However, as the results in Sobel (1998) indicate, raising tax rates to face increasing spending needs is not an option welcomed by voters: politicians who use this kind of policy are significantly more likely to be voted out of office, making this solution unattractive to electionbound officials. Additionally, some states have enacted tax limitations, which reduce the potential of this venue in times of crises. ${ }^{7}$ On the other end of the problem, spending cannot be easily downsized to match decreased revenues: states have become increasingly responsible for the provision of care for needy citizens, and these obligations only grow during economic hardships; moreover, reduction of state spending in such times can also impede the recovery of the economy. ${ }^{8}$

Fiscal gimmicks and one-time cash solutions can temporarily correct budget problems, but they do not address the problems behind the deficits. An early compilation of these strategies can be found in Kirkland (1983) who argues that they likely indicate the state officers' belief that the adjustments are meant to weather recessions while keeping an otherwise well planned and well functioning budget. Poterba (1995) and Briffault (1996) also describe some of these strategies and draw attention to their worrisome long-term consequences. Furthermore, these tricks become scarcer as time goes on and are always cosmetic operations, not fit as longterm solutions. ${ }^{9}$

Since the restrictions governments face in terms of balanced budget rules are stock in nature, states are not required to maintain spending and revenues at the same level at all times, leaving savings (such as those stored in BSFs) as a viable alternative (or complement) to smooth out consumption over the business cycle. States can save in other funds aside from the $\mathrm{BSF}$, and in the next section we discuss the factors that set apart these funds from the general

\footnotetext{
${ }^{7}$ With regard to these limits, Poulson (2005) raises the issue of the tradeoff between controlling the government's size versus diminishing the capacity to smooth out fiscal activity over the cycle.

${ }^{8}$ Lav and Berube (1999) describe in some detail the dynamics of the crisis in the early 1990s, providing examples of these issues.

${ }^{9}$ More on accounting gimmicks and how they interact with other budget policies (such as balanced budget requirements) can be found in Briffault (1996) and Rodriguez-Tejedo (2006).
} 
fund. ${ }^{10}$ As we will see, the differences between the general fund surplus and a BSF (and across

BSFs) are relevant for their effectiveness in helping states cope with recessions. These

differences can turn BSFs into relatively ineffective policy tools or significantly increase the state's capacity to weather adverse economic conditions.

Section II describes the characteristics of the funds; Section III presents a series of potential determinants for the choice of configuration of the BSFs; Section IV discusses the empirical strategy and the results and Section V concludes.

\section{Characterization of Budget Stabilization Funds.}

BSFs are simply a separate account for savings where funds can be stored during good times to withdraw them in times of need. However, what constitutes a BSF may not be unambiguously clear, as the disagreement over the nature of some funds demonstrates. ${ }^{11}$ The definition we use in this paper runs parallel to that most commonly used in the literature: ${ }^{12}$ in rough terms, BSFs are institutionalized budgetary tools that allow for the accumulation of funds during expansions for use during recessions. According to this definition, there are currently five states without a RDF: Alabama ${ }^{13}$, Arkansas, Colorado ${ }^{14}$, Montana and Oregon.

As shown in table 1, BSFs did not become commonplace until after the mid-eighties, although dates of adoption vary substantially. Earlier studies on BSFs placed much emphasis

${ }^{10} \mathrm{Hou}(2001)$ finds that BSFs have taken the lead in counter-cyclical effects of savings, while the general fund surplus has been relegated to a second place. Hou (2005) further suggests general fund surpluses may have ceased to be used for expenditure smoothing after BSFs were adopted.

${ }^{11}$ Two clear examples are Alabama's Education Proration Prevention Fund (noted as a rainy day fund by the National Association of State Budget Officers, but not by most of the literature due to its restrictive scope) and Colorado's Required Reserve (considered as a rainy day fund by both NASBO and several authors in the literature, but not by policy makers in Colorado, who repeatedly initiate petitions to amend the state's Constitution to provide for a rainy day fund).

${ }^{12}$ The point where we deviate from the literature is excluding Colorado from the list of states with BSFs. The reasons for this elimination are the exchanges with officials and policy analysts in Colorado who consider the state as lacking such funds, and the careful study of state documents regarding the Required Reserve.

${ }^{13}$ Alabama set up a reserve fund, but its resources can only be used for education so it is not considered a budget stabilization fund by most of the literature.

${ }^{14}$ Colorado has only a small emergency fund that cannot be accessed to meet economic downturns since it is reserved mainly for natural resources. State Treasurer Coffman and Dr Poulson, among others, are making strong calls for a significant BSF in Colorado that would fit the state's special framework, ruled by the presence of Colorado's Taxpayer's Bill of Rights (TABOR). See A Rainy Day Fund for Colorado, Treasure E-notes, January 2003. 
on the "lesson effect" of the crisis of the 1980s, often thought to be the cause of the cascade of BSF adoption. However, more recent research (Wagner and Sobel (2006)) suggests that this explanation may be too simplistic and overlook other factors, such as the changes in the set of restrictions and fiscal tools available to states that occurred during that period.

By establishing and funding a BSF, states may increase the amount of assets at their disposal during a crisis, ${ }^{15}$ providing a cushion that can be used as an alternative or complement to other fiscal strategies. However, this basic explanation misses the complexity of the process of saving and withdrawing embodied in the their everyday operation: Not all funds are born equal and, in fact, BSFs have diverse characteristics that introduce widely varying elements that make their operation intrinsically different from the general fund surplus. ${ }^{16}$

There is strong evidence of the importance of the configuration of BSFs. Navin and Navin (1994), through the study of BSF characteristics in the context of economic indicators, concluded that BSFs acted as countercyclical tools in only three of the Midwestern states. Sobel and Holcombe (1996) and Douglas and Gaddie (2002) consider the ability of a BSF to reduce fiscal stress during crises, and conclude that the structure of the BSF is crucial for its effectiveness -while the mere existence of a BSF has no real effects. ${ }^{17}$ McGranahan (2002) and Zahradnik and Ribeiro (2003) find that the existence of BSFs helps states weather recessions, but remark that an appropriate configuration could significantly improve their effectiveness.

Studies also exist regarding more particular venues through which states may benefit from strict funds: Gonzalez and Paqueo (2003) conclude that funds ruled by stringent requirements accumulate higher balances and reduce social sector expenditure volatility, and Knight and Levinson (1998) and Wagner (2003) find evidence suggesting that states with funds that operate under strict rules save more and receive better bond ratings, which makes future borrowing less costly for the state.

\footnotetext{
${ }^{15}$ Knight and Levinson (1999) find that states with BSFs have more savings than those without funds and, furthermore, they save more after the adoption of these funds than they did previously.

16" Budget Stabilization Funds should not be combined with general fund ending balances because these funds serve two different purposes and they generally are not interchangeable... Nevertheless, both serve a similar purpose and should be reported as resources available to a state" Fiscal Survey of the States (NASBO, July 1985), pp 18.

${ }^{17}$ Hobel and Solcombe (1996) find that BSFs with strict deposit requirements reduced fiscal stress, while the effectiveness of BSFs was not affected by the nature of its withdrawal requirement.
} 
In sum, the configuration of BSFs is a very important choice that significantly impacts the fund's effectiveness. This is not surprising, since there is wide evidence that the structure of fiscal tools (such as balanced budget requirements, tax and expenditure limitations etc) is a significant factor determining their impact on state fiscal outcomes.

There are four elements in a budget stabilization fund: deposit mechanisms, withdrawal rules, caps, and replenishment requirements. Each of them regulates the operation of a BSF in a different way, although they do not have the same importance in terms of determining thei fund's effectiveness. Because of their prevalence and their particular importance for the operation of the BSF, the deposit and withdrawal requirements are the most important characteristics embodied in the fund. Being the "gates" of the resources as they move in and out of the fund, they are key in determining its success as a stabilizing tool and we examine them in more detail now. A description of the other two rules (caps and replenishment requirements) can be found in appendix $\mathrm{A}$, and table 2 contains information on the deposit and withdrawal requirements of the funds in each state.

\section{Deposit requirements}

Deposit requirements are indexed according to the strictness of the rule from one to four, with higher numbers depicting stricter requirements, as follows:

1) Deposits made through appropriation, at the discretion of the policy maker. Under this configuration, BSFs look a lot like the general fund and many elements of substitutability between the funds are introduced

2) Deposits happen if there is a surplus in the budget. In practice, this option may be very similar to the previous one, since the existence of surplus in the budget is a decision largely in the hands of budget crafters

3) Fixed deposit, based on formulae tied to different parts of the budget (the most popular are linked to percentages of revenues or spending)

4) Deposits based on rules tied to economic growth (usually regarding the portion of the excess in the general fund to be deposited)

Formulas guarantee that the fund will actually receive revenues, forcing officials to plan on savings while drafting the budget if the conditions established by the formula are met. 
However, this does not imply that the state will necessarily save more than it would in absence of the BSF, because it could simply decide to put into the budget stabilization fund what would have otherwise been deposited in other funds. However, this is only true if the legislature had planned on saving at least as much as the formula requires; if this were not the case, the rainy day fund is effectively increasing the amount of savings made by the state.

\section{Withdrawal requirements}

Withdrawing resources from the fund can also be done in a variety of ways, ranging from discretionary appropriation by the legislature to restrictive formulae that will only allow withdrawals if the economic circumstances are severe. ${ }^{18}$ As with deposit requirements, withdrawal rules are indexed from least to most stringent as follows:

1) Withdrawals are possible through appropriation, at the discretion of the policy maker. A BSF where legislatures can access funds freely is as open to political raid as the general fund, and in this respect constitutes only a formal distinction between the two

2) Withdrawals are permitted in the event of a revenue shortfall. Although more restrictive than the previous requirement, this rule permits access to funds whether or not there is serious fiscal stress since revenue shortfalls can be triggered in a variety of ways, including cuts in taxes

3) A supermajority approval is required for withdrawal

4) Withdrawal is conditional on formulas tied to economic decline

Certain funds are reserved for certain purposes (such as education or natural emergencies), and some disagreement exists on whether funds of this nature can be considered real BSFs. ${ }^{19}$ In general (and for our purposes as well) funds that are not available for the reduction of fiscal stress during crises are not considered to be BSFs.

\footnotetext{
${ }^{18}$ Strict withdrawal requirements have real effects on fiscal outcomes. The reason follows the logic presented by Manuel Amador (2003) in the context of political economy models of government savings: "illiquidity is a useful characteristic because it reduces the temptation of current governments from overconsuming"

${ }^{19}$ For example, Hou (2001), repeatedly advocates a much more restrictive definition of what constitutes a BSF than the one usually admitted by the literature. These discussions serve to illustrate the wide range of strictness in the withdrawal requirements.
} 


\section{Factors influencing the choice of BSF configuration.}

This section presents several factors that may be relevant in the state's choice of the structure of a BSF and how they approximate or interact with what seem to be the three most important factors in the decision to configure a BSF: the uncertainty derived from the impossibility of obtaining good forecasts of future economic circumstances, the embedded uncertainty of election-driven state politics, and the existence of regulations on the budget that limit the policy maker's ability to control state finances. We briefly discuss each of them and present the associated indicators we have considered in the regressions. A more detailed description of the variables can be found in Appendix B.

The regression equations can be presented in compact form as $\mathrm{Y}=\mathrm{f}\left(\mathrm{X}_{1 \mathrm{i}}, \mathrm{X}_{2 \mathrm{i}}, \mathrm{X}_{3 \mathrm{i}}\right)$, where $\mathrm{Y}$ is the discrete variable that represents the deposit (or withdrawal) requirements, the vector $\mathrm{X}_{1}$ includes the economic variables, $\mathrm{X}_{2}$ includes the political variables, and $\mathrm{X}_{3}$ includes the variables regarding institutional structure.

Uncertainty about the future of the economy is at the core of the decision to establish a BSF: if perfect forecasting of cycles were possible, state officials could plan accordingly and smooth out consumption by saving in good times and running their reserves down during perilous times. This would not be politically taxing because it would be easy to justify both behaviors to the public under the light of the predictable nature of the state's economic cycle. However, even with state budget officers devoting much effort and resources to getting good forecasts of revenues and expenditures, these are at best good approximations that tend to get worse as the time horizon is extended and usually fail to foresee sharp downturns in state finances. In the specific economic factors we discuss below, increased income volatility, uncertainty or need may raise the optimal level of savings for the state, everything else constant, making it more desirable to establish a strict BSF.

The second source of uncertainty comes from the political process. Even politicians who are not purely self-interested need first to be (re)elected to ensure that their preferred policies will be enacted. ${ }^{20}$ The desire to remain in office, paired with the fact that state budgets often finance targeted public policies, translate into an effort to please voters at the cost of

\footnotetext{
${ }^{20}$ Poterba (1994) finds that in gubernatorial election years states enact less tax increases and expenditure reductions.
} 
shortsighted policies, or the conscious effort to set up an unfavorable environment for the successor if he happens to be of the opposite party. In either case, these non-economic objectives have the potential to create incentives for suboptimal fiscal choices. ${ }^{21}$

For the choice of BSF configuration, then, economic uncertainty calls for increased savings in the spirit of life cycle models, which -in the presence of incentives for overspending- may make institutionalized forms of savings attractive. Additionally, political uncertainty creates incentives for policy makers to consume resources while in power in a common pool problem fashion. If those who draft BSF-like funds want to reduce the effects of political uncertainty, strict rules are an attractive feature. ${ }^{22}$ On the other hand, weak RDFs may be used as a means to accommodate political needs, making weak funds more enticing.

Other factors, such as the socio-economic configuration of the state and the existing set of institutions can strengthen or weaken either motive. ${ }^{23}$ For example, BSFs could be used as means to avoid the budget rigidities imposed by other restrictions, for example balanced budget requirements or tax and expenditure limitations. It is important to consider the effects other institutions may have had in the decision to establish a certain type of BSF, since "the various institutions interact with one another in complex ways" ${ }^{24}$ and an analysis that omits these interactions is likely to provide an incomplete, or even misleading, picture.

The choice of BSF structure can be understood in the terms of a standard random utility model. Under every possible fund configuration we consider the legislature's utility, which would be a (not necessarily linear) function of the funds' characteristics, as well as the particularities of the state. A state will choose a particular configuration if its associated utility surpasses that of all the other possible configurations (and is also greater than the utility associated with not establishing a BSF at all).

To analyze this decision empirically, we use a panel dataset with information for all states that adopted such funds in the period 1951-2000 (the last year in which an adoption occurred).

\footnotetext{
${ }^{21}$ Velasco (2000) present a model in which government resources are viewed as common property and find that fiscal deficits and excessive debt emerge.

22 Mody and Fabrizio (2006) find, when studying countries in the EU, that budgets are often an expression of political rather than economic priorities, but also that budget institutions and rules have significant value in alleviating these problems.

${ }^{23}$ See Rodriguez-Tejedo (2006) for an overview of the interactions between several institutions and BSFs.

${ }^{24}$ Knight and Levinson (1998), pp 3.
} 
Since our primary focus is to investigate the determinants of the configuration choice, we include only states that adopt a BSF during our sample period. After a state adopts a fund and establishes its preferred configuration, no further observations from the state are included in the sample. ${ }^{25}$ The results are conditional on the state adopting a BSF for the first time; the model seeks to explain the factors leading to adoption (rather than adoption and retention) of the chosen structure. Seven states are excluded from our sample: Alabama, Arkansas, Colorado, Montana and Oregon (because they do not currently have a BSF), Alaska (due to the very particular nature of its BSF) and New York (which adopted its RDF before 1951).

The data used to approximate the elements that we postulate may have had an effect on the process of adoption of these BSFs are listed in the table below, grouped in three main categories: political, socio-economic, and institutional factors. Appendix B contains detailed descriptions regarding the construction of the data ${ }^{26}$, as well as some alternatives and the reasons for the choice of the variables included in the analysis.

The political science literature suggests several variables may be of importance among the first set mentioned above. In the legislative branch, the finding that larger upper houses spend more could translate into a desire for weakly configured BSFs, so funds are easily accessible. On the other hand, there is no clear result that links partisan composition to spending, leaving the relationship between the composition of the houses and the nature of BSFs as a matter open for empirical investigation. There is, however, evidence suggesting that the political affiliation of the governor (independently and jointly with the legislature's) and the existence of term limits for governors have real fiscal effects. Lastly, appointed State Supreme Courts are suggested to be more lenient, which would make deviations from strict BSFs rules easier and hence less politically constraining.

\footnotetext{
${ }^{25}$ This simplifies the empirical analysis, since it prevents the potential simultaneity bias that would occur if we were to include after-BSF years, when some of the regressors may be affected by the existence of the fund. The assumption does not stray far from reality, since only Ohio has changed the requirements of its BSF, and the procedures to change the configuration of a BSF can be quite cumbersome.

${ }^{26} \mathrm{We}$ discuss, among others, the correction of the data for the balanced budget requirement in Tennessee, the consideration of an additional measure for savings that takes into account the Census' warnings regarding the construction of series on savings and different measures for volatility. The expected effect of the variables in this context is also discussed further in this appendix.
} 
Among the socio-economic variables, we use the yearly deviation from the national mean of per capita personal income as a measure of the state's general economic condition. To investigate the effects of the sector composition of the state, we introduce the proportion of total earnings in construction, farming, manufacturing, mining and services. The effects of state's population density are unclear: a state that has to cover the public expenditure demands of a larger population may find BSFs more attractive, an effect reinforced by the public good component of savings in the RDF. However, larger states have been found to have less volatile business cycles, so they may find strict BSFs less appealing. Beyond their income, population, and economic composition, we expect states engaged in volatile spending to be in greater need for easily accessible savings, a fact that may be reflected in the type of BSF they adopt. We consider each spending type's mean standard deviation and classify the six types of expenditure in three categories (high, medium and low volatility ${ }^{27}$ ). On the other hand, we might expect states with volatile tax income to be more inclined to establish strict funds. As with spending, we include tax collection by grouping the different types of taxes according to their levels of volatility ${ }^{28}$.

Tax collections have been a decreasingly important source of income for states, followed closely by intergovernmental revenue (IG). IG revenues include local and federal transfers (with the latter making about $95 \%$ of the total ${ }^{29}$ ) and are mostly outside of state control. IG revenues are likely to decrease during periods of crises, when states need resources the most. IG finances are included in the analysis by calculating the deviation from the national mean of the per capita net IG transfers (revenues minus expenses).

\footnotetext{
${ }^{27}$ After applying the GDP deflator and calculating the overall average standard deviations, we can see that the magnitudes of the standard deviations are similar within groups and considerably different across groups, so the choice of three groups with two components seems reasonable. Education and welfare spending are the most volatile group, while expenditure in highways and health and hospitals fall in the middle category, and unemployment compensation and spending in natural resources are the relatively least volatile expenses. Although it may seem counterintuitive that education belongs in the most volatile group, we must note that capital spending in education is included in this category, which explains its variability.

${ }^{28}$ The percentages of tax income that come from severance and property taxes are grouped in the "most volatile" category, while the percentages received from sale and individual income taxes form the "least volatile" category. The percentage of tax revenues derived from corporate income taxes corresponds to the "middle volatility" group, which is used as baseline.

${ }^{29}$ As opposed to IG expenses, where local IG spending makes for most of the total expenditure.
} 
Beyond the effects of current sources of income, states can use savings in face of a recession. It is likely that states that maintain easily liquefiable resources will consider the need to establish a stringent fund as less pressing. On the other hand, it may be possible that states that decide to have more savings in the form of cash and securities have a preference for sound savings, and would be more inclined to establish strict funds. Since it is difficult to intuitively or theoretically establish a predicted sign for the relationship between other savings and the nature of BSFs, it remains a question best answered empirically. Aside from using reserves, states can increase the resources they derive from taxation. However, states that exert higher levels of tax effort will have less room for tax increases, making meaningful BSFs more attractive. On the other side of the spectrum, our a priori expectation is that states with higher levels of debt will be, all else constant, more inclined to establish demanding BSFs, since they it would be relatively more costly for them to go further into debt. However, high levels of per capita debt may be correlated with higher tolerance for debt in the state, which could overcome the aforementioned effect. The final effect of indebtness on BSF rules is then left to empirical investigation.

Among the institutional constraints, tax and expenditure limitations (TELs) restrict the state's ability to cope with recessions through direct action, which may make meaningful BSFs more attractive. On the other hand, RDFs may be seen as a way to put funds outside of the scope of the TELs, allowing for higher discretion in the spending decisions, a proposition for which Wagner and Sobel (2006) find supporting evidence. We have explored different alternative measures of TELs, using dummies for the existence of each of these limitations as well as Poulson's (2005) indexes of TEL strictness. Another important institutional constraint is given by the existence of balanced budget requirements (BBR). States with demanding BBRs enact more restrictive spending policies (Poterba (1994)), fare better in deficit control (Alesina and Bayoumi (1996)), are more likely to enact tax increases and spending cuts during recessions (Alt and Lowry (1994)) and tend to save more (Bohn and Inman (1996)), but strict BBRs also introduce rigidities in fiscal policy (Alt and Lowry (2001)) and may exacerbate business cycle volatility (Levinson (1998)). Demanding BBRs make meaningful BSFs more appealing, since intertemporal smoothing becomes more difficult. The last institutional factor is embedded in the BSFs themselves. Their legal nature (statutory or constitutional) can also play a role on the configuration of deposit and withdrawal requirements. Constitutionally 
established budgetary tools allow decision makers less freedom when establishing the particulars of the law and have been shown to have stronger effects on fiscal policy than their statutory counterparts.

\begin{tabular}{|c|c|}
\hline Variable & Source \\
\hline \multicolumn{2}{|l|}{$X_{1}$ - Political variables } \\
\hline \multicolumn{2}{|l|}{ Number of seats in upper House } \\
\hline Number of seats in lower House & \multirow{4}{*}{$\begin{array}{l}\text { ICPSR study \#0016, Statistical Abstracts of the US, } \\
\text { Minnesota Legislative Reference Library. }\end{array}$} \\
\hline$\%$ seat gap between main parties (Upper House) & \\
\hline$\%$ seat gap between main parties (Lower House) & \\
\hline Democratic Governor (dummy) & \\
\hline Appointed Supreme Court (dummy) & Bohn and Inman (1996) \\
\hline Limit for governor's tenancy (dummy) & Council of State Governments \\
\hline Citizens' ideology & \multirow{2}{*}{ Berry, Ringquist, Fording, and Hanson (1999) } \\
\hline Governments' ideology & \\
\hline \multicolumn{2}{|l|}{$\overline{X_{2}-\text { Socio-economic variables }}$} \\
\hline Deviation from average per capita personal income & Bureau of Economic Analysis \\
\hline Percentage of earnings - by sector & Bureau of Economic Analysis \\
\hline Deviation from average per capita savings & US Census Bureau \\
\hline Percentage of tax revenue - by degree of volatility & \multirow{3}{*}{$\begin{array}{l}\text { Census of Governments and the Historical Statistics of } \\
\text { the United States. }\end{array}$} \\
\hline Percentage of expenditure - by degree of volatility & \\
\hline $\begin{array}{l}\text { Deviation from average per capita net } \\
\text { intergovernmental revenue }\end{array}$ & \\
\hline Tax effort & $\begin{array}{l}\text { Advisory Commission of Intergovernmental Relations } \\
\text { and Tannenwald (2000) }\end{array}$ \\
\hline Deviation from average per capita debt & US Census Bureau \\
\hline Population density & Statistical Abstracts of the United States \\
\hline$X_{3}$ - Institutional variables & \\
\hline Constitutional BSF (dummy) & Wagner (2001) \\
\hline Expenditure limitation (dummy) & Rueben (1995), Waisanen (2005) and Poulson (2005) \\
\hline Stringency of the balanced budget rule & $\begin{array}{l}\text { Advisory Commission of Intergovernmental, National } \\
\text { Association of State Budget Officers, personal } \\
\text { communication with Tennessee's Department of } \\
\text { Finance and Administration }\end{array}$ \\
\hline
\end{tabular}




\section{Empirical strategy and results.}

Since the dependent variables are not continuous, the estimation of the coefficients with an OLS regression would not be correct ${ }^{30}$. The actual "distance" between two consecutive numbers is unknown and is likely to be different so more appropriate estimation methods are considered below. Our characterization of the dependent variables (rules for deposit and withdrawal) allows us to use multinomial and ordered techniques that provide new insights into the rationale for the configuration of BSFs. The final choice between the explanatory variables is conditioned by the constraints posed by data restrictions, which limit the number of parameters that can be estimated.

An important characteristic of the deposit and withdrawal requirements is that they can be classified according to their level of stringency. That is, we can classify funds according to how easy or difficult it is to control the moneys that go in or out of the fund and assign numbers to each characteristic to reflect this fact. For that purpose, we assign numbers one to four for the deposit and withdrawal requirements embodied in each BSF. ${ }^{31}$ The actual values are irrelevant beyond reflecting that outcomes with larger values correspond to "stricter" requirements. We can take advantage of the ordinal multinomial nature of the data by estimating ordinal logistic regressions. The structural model for an ordered logit (or proportional odds model) is given by $\mathrm{yit}{ }^{=}=\mathrm{x}$ it $\beta+\varepsilon$ it, where $i$ indexes the state, $t$ the year and $\varepsilon$ is a disturbance with logistic distribution. In the most general case we consider (with four possible categories), the model can be expressed in terms of probabilities as:

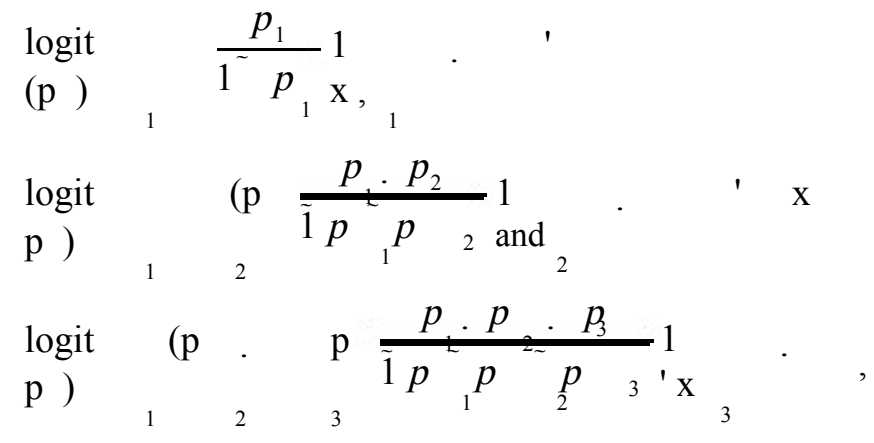

with $\mathrm{p}_{1}+\mathrm{p}_{2}+\mathrm{p}_{3}+\mathrm{p}_{4}=1$ and $\alpha \quad{ }_{1}<\alpha_{2}<\alpha_{3} \quad{ }_{3}<\alpha$

4.

\footnotetext{
${ }^{30}$ OLS equivalents of the models were calculated for comparison purposes, and are available upon request. As expected, all the models considered performed better than their OLS counterparts.

${ }^{31}$ Meaning that requirements of type "four" are stricter than those of type "three", "two" and "one", requirements of type "three" are stricter than those with values "two" or "one" and so on.
} 
The ordered logit (OL) assumes that all the coefficients on the independent variables are equal for every category of the dependent variable, so the slopes of the estimated equations are identical. This is known as the parallel equation assumption (or proportional odds assumption, because the odds ratio of $\mathrm{Y} \leq \mathrm{j}$ is the same for all categories.) The assumption can be tested using a Brant's test ${ }^{32}$ (Brant (1990)) or a likelihood ratio test, which provide evidence suggesting that the parallel regression assumption is violated. This is not a rare occurrence, since the proportional odds assumption is often violated (Long and Freese (2006)), even with large samples and no a priori reason that would justify the violation. ${ }^{33}$ It is in the spirit of this literature that we report the OL results even when the proportional odds assumption seems to be violated, but keeping in mind that the estimates may be misleading.

The results of some relevant models appear in tables 3 and $4,{ }^{34}$ which report changes in marginal effects rather than coefficients. From these tables we can see that states with larger Senates are more likely to establish weak deposit requirements, and higher fragmentation of the Lower House (measured as the percentage gap in the number of seats held by the two main parties) reduces the likelihood of establishing demanding requirements. These effects persist even when controlling for various other political circumstances. Our results run parallel to Matsusaka's (1995), who concludes that larger upper houses (but not lower houses) are significantly associated with higher spending but does not find such effects for the existence of divided governments. Other results (not shown) also fail to find any significant relationship between the affiliation of either the legislative or executive branches and the configuration of a BSF. Additionally, there seems to be some weak indication (regressions not shown) that more liberal governments are more likely to adopt weak withdrawal requirements. Among the group of economic characteristics, states that spend comparatively more on high-volatility spending appear to be more likely to establish weak rules, while states with higher levels of debt are less likely to establish weak withdrawal requirements. Within

\footnotetext{
${ }^{32}$ Formally, the Brant test's null hypothesis is that the coefficients remain the same across categories. A p-value lower than 0.005 indicates that the impact of the independent variables is different across categories, and the violation of the proportional odds assumption.

${ }^{33}$ Williams (2006) cites Sarah Mustillo saying "neither of us [referring to herself and a colleague] has ever run an ologit model that DID NOT violate the proportional odds assumption. My models always fail the Brant test".

${ }^{34}$ Following Long and Freese (2006) we report the McKelvey and Zavonia's $\mathrm{R}^{2}$, which has been shown by Hagle and Mitchell (1992) and Windmeijer (1995) to be closest to the $\mathrm{R}^{2}$ of a linear model estimated using the underlying latent variable.
} 
the institutional data, our results suggest that constitutionally configured BSFs are more likely to include strict operating rules.

However, it is plausible that we are indeed facing a true violation of the parallel equation assumption. Aside from modifying the model, other solutions exist. For example, ignoring the ordinal nature of the dependent variable and restricting the analysis to multinomial logits, or using generalized ordered logits (that allow the effects of the explanatory variables to vary with the point at which the categories of the dependent variable are dichotomized).

Ignoring the ordinal nature of the dependent variable does not bias the coefficients, although it may lead to loss of efficiency. Two logit models are commonly used: the multinomial logit (or generalized logit model) and the conditional logit. ${ }^{35}$ For the more disaggregated case, the probabilities of adoption in the multinomial case can be expressed as: $\mathrm{P}(\mathrm{y}=\mathrm{i})=\exp \left(\beta \mathrm{i}^{*} \mathrm{x}\right) / \Sigma \quad \mathrm{j} \neq \mathrm{i} \exp \left(\beta \mathrm{j}^{*} \mathrm{x}\right)$ for $\mathrm{i}=1,2,3,4$. As usual, for the system to be identified, we need to set one of the coefficients equal to zero and refer the analysis as compared to the reference group, and the coefficients on the other (non-reference) groups can be interpreted as log odds of being in a particular group as compared to being in the reference group.

A potential for bias in the estimation of the multinomial logit (MNL) exists, brought about by the independence of irrelevant alternatives (IIA) assumption (or the independence in competing risks assumption). In our case, the IIA translates into a risk for bias if we include BSF configuration alternatives that are not available to legislatures, or if we are presenting as different choices configurations that are in reality very close substitutes. The latter could be a problem if in fact some of our four categories are close substitutes. Reducing our classification from four to two and three categories will provide some rough idea on whether this is actually a serious problem. ${ }^{36}$

\footnotetext{
${ }^{35}$ We choose the multinomial logit as opposed to the conditional logit model because the former is used when the independent variables refer to characteristics of the units, while the second one is usually employed when the independent variables are characteristics of the choices.

${ }^{36}$ The Hausman-McFadden (1984) test for IIA in the four-category case suggests that independence may actually exist. However, there are known problems with this test that make its validity questionable. A more reliable test (the Small-Hsiao (1985) test) produces mixed results that suggest that the IIA assumption may be violated. When we restrict our characterization of the deposit and withdrawal requirements to two categories ("strict" vs "lax") both the Hausman-McFadden and the Small-Hsiao test indicate that the IIA assumption holds. With the three categories split, again we find the same discordance between the Hausman-McFadden and the Small-Hsiao tests as we did in the four-category case.
} 
As with the ordered logits, the partial derivative of the probability of a given choice does not correspond with the associated regression coefficient, so caution must be used when interpreting the results. Examination of tables 5 and 6 reveals similar results to those of the ordered regressions in terms of the political variables: states with bigger senates are more likely to establish weak rules, higher fragmentation in the lower House reduces the probability of adopting strict requirements, ${ }^{37}$ and states with more liberal institutions seem to be more likely to establish weak requirements. The MNL results suggest that additional factors may be of relevance: states with appointed supreme courts are more likely to establish strict deposit rules, providing some support for the possibility that deviations from the rules may be easier under this type of Supreme Court, reducing the cost of adopting stringent requirements. As before, the results indicate that constitutional RDFs are more likely to be endowed with demanding rules.

Among the economic variables, we still find a significant increase in the odds of adopting weak rules for states that are comparatively more engaged in highly volatile spending or whose earnings are comparatively more dependent on agriculture. Additionally, the MNL results suggest that states with higher levels of tax effort may be more prone to establishing strict deposit rules. In the tax structure, higher reliance on volatile tax sources seems to increase the odds that a state will choose a strict deposit requirement.

Other alternatives, besides the usage of MNL, to solve the problem of violation of the parallel equations assumption exist. The proportional odds assumption is violated if some (or all) of the coefficients in the J-1 regressions are found to be statistically different, so that the estimated lines are not parallel. The generalized ordered logit (GOL) model solves this problem by allowing the coefficients to differ across categories. Although promising, this method is problematic in our case due to the high number of parameters that need to be

\footnotetext{
Although Wald tests for the possibility of amalgamation of the categories suggest that none is possible, the associated chi square values for the test for the reduction of categories 1 and 2 into a single group is much smaller than the rest, suggesting that categories 1 and 2 may be much more similar than the others (as we expected them to be). Additionally, the likelihood ratio test suggests that categories 1 and 2 may be indistinguishable.

${ }^{37}$ Our results are consistent with Wallis' assertion that "states where politics were the most competitive, where both parties were most responsive to voters' concerns, were the states more likely to adopt new constitutional provision." (Wallis (2005), pp 29).
} 
estimated, which may render the estimation of generalized ordered logit difficult. ${ }^{38}$

intermediate solution is presented in Bercedis and Harrell (1990) and Williams (2006): they propose the estimation of a generalized ordered logit where some of the coefficients are fixed across equations while others are allowed to vary. We still need to explore this method, given the nature of our data it might prove to be useful. The stereotype ordered model is a compromise between the MNL and the ordered logit, which can be used in a case like this when there is some indication that some alternatives are very similar. ${ }^{39}$ Other non-ordered alternatives to multinomial logits yet to be explored are the multinomial probit (MNP) model and nested logit model (NL). MNPs, while being similar to MNLs, have the advantage of assuming an arbitrary covariance structure for its multinomial normal distribution, allowing arbitrary correlation between the utilities of each choice. However, the large number of parameters that have to be estimated may make this method unattractive in our case. NLs create a hierarchical structure, grouping choices into categories within which the IIA is assumed to hold. However, two problems exist with this approach: the number of parameters to estimate may be too high for our problem, and it is not clear how to group the four levels of stringency in such a way that the IIA will hold (the best option, which is the one we present here, may be to collapse categories 1 and 2 in a single group, and 3 and 4 in another). Alternatively, the NL model is a potential solution to bring into the analysis states without BSFs, making the choice of establishing a BSF into the first decision nodule and considering the decision about the type of fund a second-level choice.

It is not a priori clear what the preferred model for our problem may be. In theory, given the ordered multi-dimensional nature of the deposit and withdrawal requirements and the evidence suggesting that the parallel equation assumption may not be satisfied, a generalized ordered logit may be the best fit. However, we run into the problem of having to estimate too many parameters. The partial generalized ordered logit could be a solution to this problem that needs to be considered. Alternatively, multinomial logits ignore the ordered nature of the deposit and withdrawal requirements, but capture the multidimensionality of the requirements.

\footnotetext{
38 Indeed, many of our generalized ordered logit regressions have difficulty converging.

39 Lunt (2001) presents the stereotype ordinal regression model as a method to impose "ordering constraints" in a MNL.
} 
According to the measures of fit there seems to be some indication that MNL may be a better fit than the OL for the problem at hand. More support for this claim can be found in the plots of the predicted probabilities of the OL and MNL models: there is a sudden truncation of the ordered logit model's distribution that seems unrealistic, suggesting that the multinomial logit may be a better model for the data. ${ }^{40}$ However, preliminary work with intermediate techniques suggests these may provide better fits for the model while taking into account the ordered nature of the data.

Beyond the search for the best fit, there is an inherent usefulness in the comparison of various plausible models. It allows us to see the data under different alternatives, with various specifications and a diverse set of assumptions and provides, in its own way, checks for robustness of any estimated coefficient.

\section{Conclusions.}

BSFs have become popular among states as tools to help them weather recessions and other adverse conditions. However, they are very disparate in nature and the differences in terms of deposit and withdrawal requirements have a significant impact on their effectiveness. This paper investigates the factors that determined the choice of BSFs' configuration, using data from the second half of the twentieth century and amplifying or modifying the set of indicators used in the previous literature. In particular, we corrected the figure for the stringency of Tennessee's BBR, considered a new measure of the resources easily available to the states (proposing an alternative to the figure of savings that had been previously used, which is advised against by the Census), introduced additional indicators of the political, economic and institutional particulars of the state, and proposed new methods that incorporate the ranked nature of the two requirements that have been proved to significantly affect the effectiveness of these funds: deposit and withdrawal rules.

Our results provide several insights: one suggests that the two most lax categories of deposit and withdrawal requirements may be indistinguishable, so the possibility of

\footnotetext{
${ }^{40}$ The correlations between the sets of predictions for ordered logits and multinomial logits are not very high (about 0.6 [0.4] for lax [strict] deposit requirements and 06 [0.7] for lax [strict] withdrawal requirements).
} 
collapsing them when analyzing BSFs should be considered. A second result has to do with the methodology used: intuitively, ordered techniques should be employed when analyzing these funds, but the violation of the proportional odds assumption makes the OL model unreliable. Tentative work with generalized ordered logit suggests this option may be superior to MNL, and further investigation is under way to apply intermediate techniques that would incorporate a sense or ordering into the analysis without imposing excessively restrictive assumptions. A lesson can be drawn from this against lightly ignoring the ordered nature of the requirements or assuming that the proportional odds assumption holds.

Turning to the investigation of the factors that determined the decision to configure these funds ${ }^{41}$, we find indications that bigger Senates are conducive to laxer deposit requirements and that more fragmented lower houses (which generally have high levels of control over the budget and more members) may be correlated with less stringent BSFs ${ }^{42}$.

Among the economic variables, we find some evidence suggesting that states with higher levels of debt are more prone to establish weak deposit requirements but stricter withdrawal rules, and that the state earning's composition may be a factor to take into account ${ }^{43}$. Additionally, we find evidence that states receive higher percentages of their total tax income from relatively more volatile sources show some inclination to establish funds with stricter deposit requirements, as do states with higher levels of tax effort. Both effects provide some indication in favor of the hypothesis that states adopt these funds to accumulate resources in order to weather recessions. However, states that spend a higher proportion of their budgets in volatile spending categories are more likely to establish weak funds.

Other state institutions are relevant in the configuration decision, in line with Poterba's (1994) suggestion that fiscal tools should not be studied individually. Firstly, states with

\footnotetext{
${ }^{41} \mathrm{We}$ do not have enough data to allow us for clustering by year. We have, however, run our regressions with clustering by economic cycle using the business cycles data reported by NBER. The resulting estimates are smaller in magnitude but none of the significant coefficients switches signs.

42 Besley and Case's (2001) finding that fiscal cycles exists in states where limits to governor tenure are binding may help explain why we find weak and scattered indications linking the existence of these rules with increases in the likelihood that a state will institute strict requirements for its BSF.

${ }^{43}$ To take into account the possibility of regional effects, we run our regressions clustering using the BEA-defined regions and included regional dummies. When including regional dummies, the variables representing the New England states (Connecticut, Maine, Massachusetts, New Hampshire, Rhode Island, Vermont) and the South Atlantic states (Florida, Georgia, North Carolina, South Carolina, Virginia) were significantly more likely to adopt weak funds.
} 
stricter balanced budget requirements seem to be less likely to establish demanding deposit requirements (although no such result appears regarding withdrawal requirements). Also, although the mere existence of tax and expenditure limitations is not a significant factor in the configuration choices of states' RDFs, the part of the budget to which they apply is. In particular, the existence of more comprehensive TELs increases the likelihood that states will adopt weak deposit requirements, which suggests RDFs may be an attempt to avoid the restrictions imposed by these limits. Additional support for this idea comes from the results suggesting that BSFs that were not established by the legislature, but rather by voters, and that were embedded into the state constitution are more likely to have a strict configuration.

Further work includes the investigation of the simultaneous choice of deposit and withdrawal requirements, with measures of the overall level of stringency of the fund and simultaneous estimation of deposit and withdrawal choices. Also, additional work on the importance of the ordered nature of these rules is needed. Alternative methods were briefly discussed that take into account the fact that the trade-off between number of parameters to estimate and potential explanatory variables is of great importance and needs further consideration.

The results of this study provide a stepping-stone to the discussion of this rather recent fiscal tool. BSFs have been found to have the potential to significantly reduce fiscal stress, but only if they are properly configured. Their impact on budget stabilization takes many forms: adequately designed BSFs improve the state's credit rating, reduce the need for hurried solutions to cash shortages (such as unplanned tax increases or cuts in spending) and significantly reduce the volatility of expenditure -in particular, social spending,

Our results suggest that economic conditions, such as the levels of tax effort or volatility of state spending, are important factors for the choice of regulations embodied in these funds. However, we have gathered some evidence that indicates that factors other than budget stabilization may help explain the weak -and ineffective- configuration of many funds. Political factors, as well as other institutional constraints, also provide incentives that explain the configuration of the funds. 
Given the importance of these rules, states reconsidering the nature of their funds may benefit from rethinking the reasons that led to the actual configuration and include them in their discussions about the possibility of change.

These lessons may also be valuable for other countries, where increased subnational government fiscal responsibilities could make instruments for budget stabilization at these levels an attractive option. As with the U.S. experience, the institutional details of these funds are likely to be of major importance. Others who may consider establishing funds like these could benefit from the awareness of considerations other than economic reasons that have impacted the choices embedded in BSFs.

\section{Appendixes and Tables.}

\section{Appendix A - Other RDF rules.}

\section{Caps}

$5 \%$ (usually of expenditure, although other bases exist) is a common number for rainy day fund caps ${ }^{44}$ and one that is widely accepted to have spread from a comment by a rating agency executive ${ }^{45}$, which is why we are not considering it in our analysis. However, there is wide evidence that for most states $5 \%$ would not suffice in the face of an economic downturn ${ }^{46}$ (see, for example, Lav and Berube (1999), Joyce (2001), Kriz (2003), and Wagner and Elder (2003)). The question then turns to what this limitation could do to the operation of the fund if it was to be binding and what it signals with respect to the general philosophy that governs the fund. Establishing caps for the RDF balance has the potential to reduce its stabilization ability if the

\footnotetext{
${ }^{44}$ Caps are most frequently set at $5 \%$, but $7 \%$ and $10 \%$ are also common figures. The overall average cap is slightly above $6 \%$.

${ }^{45}$ The 5\% number was inspired by declarations from Robert $\mathrm{H}$. Mueller who, while being vice assistant to the Standard and Poor Corporation and later vice president of the Morgan Guarantee Trust, referred to it as a "key financial number" and a "good solid number for a state surplus."

${ }^{46}$ A 1999 report by the Center on Budget and Policy Priorities set the overall desirable level for a BSF at a low of 15 percent of a year's worth of expenditures. The Government Finances Officers Association recommends maintaining a minimum of between 5 and $15 \%$ of regular general fund operating revenues or no less than one-two months worth of general fund operating expenditures as unreserved fund balance in the state's general fund, although notes are made to clarify that significantly higher balances may be needed for some governments in special circumstances, and that these figures should be placed in a long-term context to avoid putting excessive emphasis on transitory situations.
} 
limit was to be binding and the recession deep enough to make desirable the presence of higher balances. ${ }^{47}$

\section{Replenishment requirements}

Replenishment requirements call for a refilling of fund coffers within a certain period of time. They have not received as much attention from the literature as the other three rules, perhaps because they are a rare feature among the funds. However, replenishment requirements are often cited in the political and academic circles ${ }^{48}$ as being a restriction that can potentially render the fund useless, since the state could decide not to use it in a year of recession under the fear of the obligation of having to replenish the fund in the near future when the situation (far from getting better) may be getting worse. We do not pursue their analysis further due to their relatively low implementation and the fact that states are taking steps towards modifying or entirely eliminating these restrictions.

\section{Appendix B - Description of the data.}

Among the political variables, we include measures of House composition and fragmentation, ${ }^{49}$ as well as indicators of divided control, affiliation of the executive, appointment method of the Supreme Court and ideology measures.

We expect the size of the Houses to matter in light of the findings that states with larger Houses spend more. This effect can be explained using Tullock's (1959) theory of the tragedy of the commons: government spending typically benefits a small fraction of the population, while the taxes used to fund it are spread among all taxpayers. Weingast et al (1989) formally expressed this issue in the "law of $1 / \mathrm{n}$ ", where $\mathrm{n}$ represents the number of districts. They show that constituents only pay one $\mathrm{n}^{\text {th }}$ of any public spending they receive, becoming obvious that

\footnotetext{
${ }^{47}$ It seems that the caps have indeed been binding: The National Association of State Budget Officers reported in 2004 that the average total balance for rainy day funds in the period 1979-2003 was 5.2 per cent (Budgeting Amid Fiscal Uncertainty, NASBO 2004).

${ }^{48}$ See Lazere (2003) and recommendations of the Office of the State Budget Director of Kentucky for examples of arguments against the existence of replenishment requirements.

${ }^{49}$ Given its unicameral nature, wherever bicameral measures are computed, Nebraska is excluded from the regressions. Although the choice between bi and unicameralism is potentially relevant in fiscal terms, Heller (1997) shows that bicameralism may lead to higher deficits) the fact that only one state has opted to operate with only one House makes it impractical to consider its implications for BSF choices.
} 
spending increases with the legislature size. Gilligan and Matsusaka (1999) provide a model that links the ability to alter fiscal policy by gerrymandering with the number of seats. These theories appear to be supported by the data: Gilligan and Matsusaka (2001) find that larger upper houses are associated with higher spending (independently of the composition of the legislature) through the 20th century, ${ }^{50}$ this does not, however, apply to the Lower House. ${ }^{51}$

The composition of the legislature has also been shown to be relevant in fiscal outcomes. ${ }^{52}$ Poterba (1994) finds that having a divided government slows a state's reaction to a fiscal crisis; Crain and Muris (1995) conclude that divided governments spend less, while Gilligan and Matsusaka (1995) fail to find significant effects. Alt and Lowry (1994) provide a theoretical framework to explain the importance of partisan composition for state fiscal policy and, for the period 1968-87, find empirical evidence suggesting that democrats tend to tax and spend more and that divided governments have a reduced capacity to respond when facing revenue shocks. To investigate the extent of the importance of these two factors for the choice of BSF configuration, we consider the number of seats as well as the percentage gap in the numbers of seats held by each of the two main parties. Data come from the Inter-university Consortium for Political and Social Research (ICPSR) study $\# 0016^{53}$ and, since 1985, from the Statistical Abstract of the United States. ${ }^{54}$

The affiliation of the governor is also relevant for state budgeting: ${ }^{55}$ governors submit budgets, can veto bills, and have in general a wide array of executive powers that can affect state fiscal policy. This effect can be particularly noticeable if the legislative and executive powers are of opposite political parties. ${ }^{56}$ To investigate these possibilities, specifications with

\footnotetext{
${ }^{50}$ Due to data constraints, the years corresponding to World War II are excluded from their analysis.

${ }^{51}$ Gilligan and Matsusaka (2001) did several robustness checks to investigate the theoretically puzzling effect of the disparity of effects across Houses, the result always remained the same.

${ }^{52}$ Gilligan and Matsusaka (1997) and McCarty (1999) provide brief reviews of theories and empirical applications for the interested reader.

53"Partisan Division of American State Governments, 1834-1985"

${ }^{54}$ Since neither source had information for Minnesota before 1974, the data compiled by the Minnesota Legislative Reference Library using unofficial legislative directories of the Minnesota Railroads Association was used instead.

${ }^{55}$ Lowry et al (1998) find that gubernatorial electoral effects of an increase in the size of the state budget vary by party: Republican candidates loose votes, while Democrats may be rewarded.

56 Krause (2000) finds that, during the period 1948-95, ideological divergences across the different branches of the federal government were related with fiscal deficit. At the state level, Alt and Lowry (1994) find that Democrats tax and spend more, and divided governments are less able to react to revenue shocks. Additionally, Alt and Lowry (2000) explain how a governor's budget proposal may be
} 
a dummy taking the value of 1 if the elected governor belongs to the Democratic Party and/or interactions with the polarization measures explained above were included. Also, 36 states currently have a limit on how long governors can serve, since term limits have been receiving considerable attention in the literature as a potential way to limit government and encourage fiscal responsibility (Basham (2001) and New (2001)) a dummy variable that takes the value of one every year after a term limit is adopted is also included.

An alternative measure of the political structure is presented in Berry et al's (1999) measures of citizen and government ideology. From their data we can see that, on average, the governments' ideology leans more towards liberalism than the citizens' during most of the period, ${ }^{57}$ and it seems to be more volatile - with a standard deviation $50 \%$ higher than that of the citizens' index.

Lastly, the appointment method of the State Supreme Court (elected vs appointed) is included due to the fact that judges often enforce fiscal rules. Bohn and Inman (1996) report that elected Supreme Courts are associated with larger surpluses in state budgets, as compared to surpluses in states where courts are appointed. Using their data on the nature of the courts, a dummy variable that takes the value of one if the Supreme Court is elected and zero otherwise is included in the regressions. The cost of establishing a strict BSF (in terms of loss of flexibility for policy making) is likely to be lower if the Court is appointed, because appointed judges may be more amiable to deviations from the rule. Hence, we expect states with appointed courts to be more prone to establishing demanding BSFs.

Among the socio-economic variables, we chose to use the yearly deviation from the national mean of per capita personal income ${ }^{58}$ as a measure of the state's general economic condition ${ }^{59}$ (and, to some extent, the needs of its population) rather than gross state product. ${ }^{60}$

rejected by a legislature of the opposite sign, the budget may then remain in the status quo if the governor decides to veto the legislature's preferred proposal and the opposing party in the legislature is not able to override the veto in both chambers.

${ }^{57}$ The only two exceptions are the periods 1967-73 and 1996-02.

${ }^{58}$ Calculated using the per capita personal income data from the Bureau of Economic Analysis. An indetail description of the methodology used for the construction of this measure can be found in their methodology section. Alternatively, we also calculated moving averages of per capita personal income, but settled for using the standard deviation.

59 The Advisory Commission of Intergovernmental Relations (ACIR, 1987) pointed out that personal income is a powerful determinant of state fiscal behavior, surpassing in importance the set of budgetary constraints. 
The effects of state's population density are unclear: a state that has to cover the public expenditure demands of a larger population ${ }^{61}$ may find BSFs more attractive, ${ }^{62}$ an effect reinforced by the public good component of savings in the RDF. However, larger states have been found to have less volatile business cycles, so they may find strict BSFs less appealing. In sum, the effects of population on budgetary outcomes are unclear, as is its impact on BSFs configuration. Beyond their income and population, we expect states engaged in volatile spending to be in greater need for savings, a fact that may be reflected in the type of BSF they adopt. To investigate the effects of the sector composition of the state, we introduce the proportion of total earnings in construction, farming, manufacturing, mining and services, using the data on earnings provided by the Bureau of Economic Analysis (BEA). ${ }^{63}$ In graph 1 we can observe the evolution over the period of the average percentages of each of the categories. Both services and manufacturing have grown in absolute terms but, as we can see from the percentage distribution, the increase in services has occurred mostly at the expense of a decline in the relative importance of manufacturing in the average state economy.

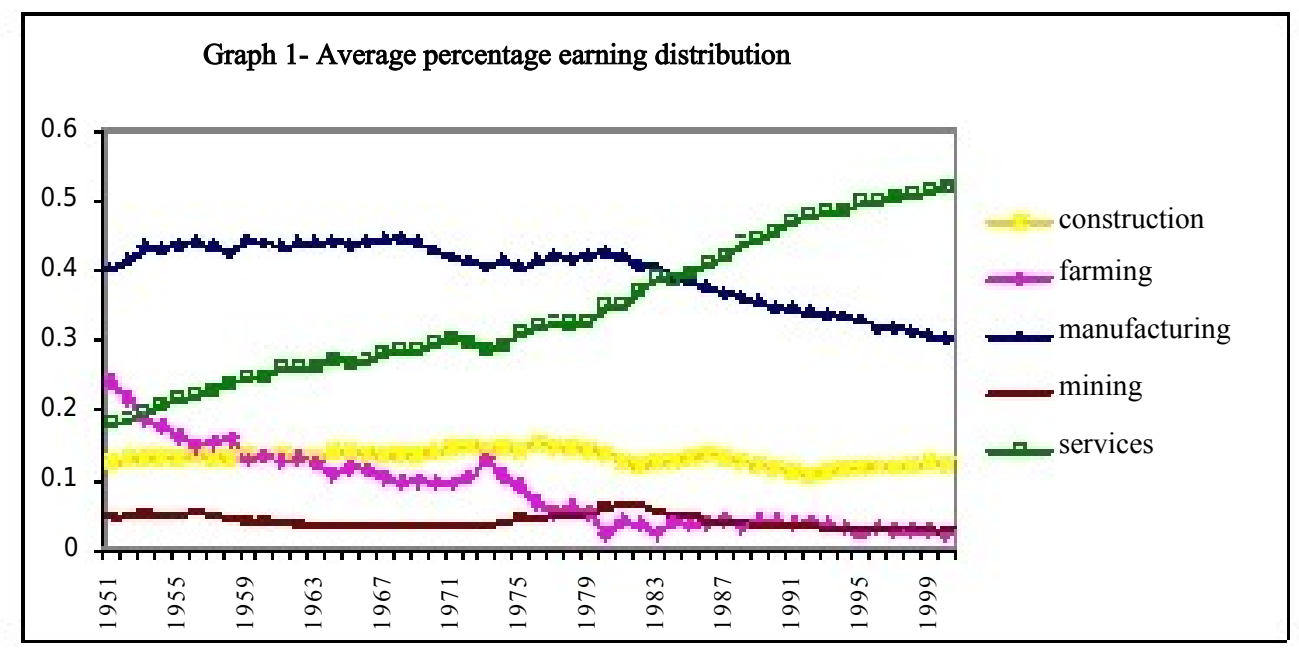

\footnotetext{
${ }^{60} \mathrm{We}$ also performed the analysis using yearly deviations from the national GSP mean instead of per capita personal income for the years in which the data is available, and the results turned out to be very similar.

${ }^{61}$ Sawicky (2003) has proposed a measure for adjusted population that reflects the actual pressure on state finances better than raw numbers on population (adjusting for population in poverty, unemployment rates and the state's fiscal capacity). The data to construct indices of this nature is however not available for our sample period.

${ }^{62}$ Oates (1988) finds evidence in local governments for what he calls the "zoo effect", that is, larger localities may be able to provide a wider range of services.

${ }^{63}$ I would like to thank Dr. Jeff Werling, from the Interindustry Forecasting center (Inforum) at the University of Maryland, for his assistance in acquiring the BEA data.
} 
The different types of state revenues and expenses are also included in the regressions as percentages rather than actual levels, grouped according to their level of volatility, which avoids the scale and trend issues that would occur if we included raw dollar amounts. Also, this modification addresses the issue of high multicollinearity between our dependent variables. ${ }^{64}$ Furthermore, including these percentages allows us to investigate the effect of spending and taxing compositions on the decision of BSF configuration.

In particular, total spending is not very helpful for our purposes, since not all types of government expenditures behave in the same way during recessions. Some types are less amenable to policymakers' decisions, or are more visible to the public (so they may trigger stronger responses if cuts are needed during recessions), providing extra incentives to establish solid BSFs. Since we are interested in the impact of expenditure volatility and to avoid issues of high collinearity between the different types of expenditure, we go beyond the functional nature of the different types of expenditure and group them instead with respect to their degree of volatility. We consider each spending type's mean standard deviation, following an approach similar in spirit to the calculations of Lane (2003) ${ }^{65}$ and classify the six types of expenditure in three categories according to their volatility ${ }^{66}$ (high, medium and low) including in our regression the state's percentages in the most and least volatile categories and leaving the middle group as baseline. ${ }^{67}$

64 Since the Variance Inflation Factor suggested high levels of collinearity, principal component techniques were used to reduce the dimensionality of the dataset. However, the decision for maintaining a certain number of eigen-vectors was often not clear-cut, and since a conservative use of the Kaiser and Scree criteria led to relatively small reductions in dimensionality we opted for transformations of the independent variables to avoid obscuring their relationship with the dependent variable.

${ }^{65}$ Lane (2003) calculates output volatility measured as the standard deviation of output growth.

${ }^{66}$ After applying the GDP deflator and calculating the overall average standard deviations, we can see that the magnitudes of the standard deviations are similar within groups and considerably different across groups, so the choice of three groups with two components seems reasonable. Education and welfare spending are the most volatile group, while expenditure in highways and health and hospitals fall in the middle category, and unemployment compensation and spending in natural resources are the relatively least volatile expenses. Although it may seem counterintuitive that education belongs in the most volatile group, we must note that capital spending in education is included in this category, which explains its variability.

${ }^{67}$ Alternatively, we followed the method Holcombe and Sobel (1997) developed to generate long-run and short-run variability of state income and calculate each state's yearly deviation from the national mean. The basic equation is given by: $\ln \Delta$ (Expenditure type) $=\alpha+\beta \ln \Delta$ (per capita personal income) + $\varepsilon$. Taking the growth rate does not make the series stationary (and $\beta$ is a measure of the long-run 


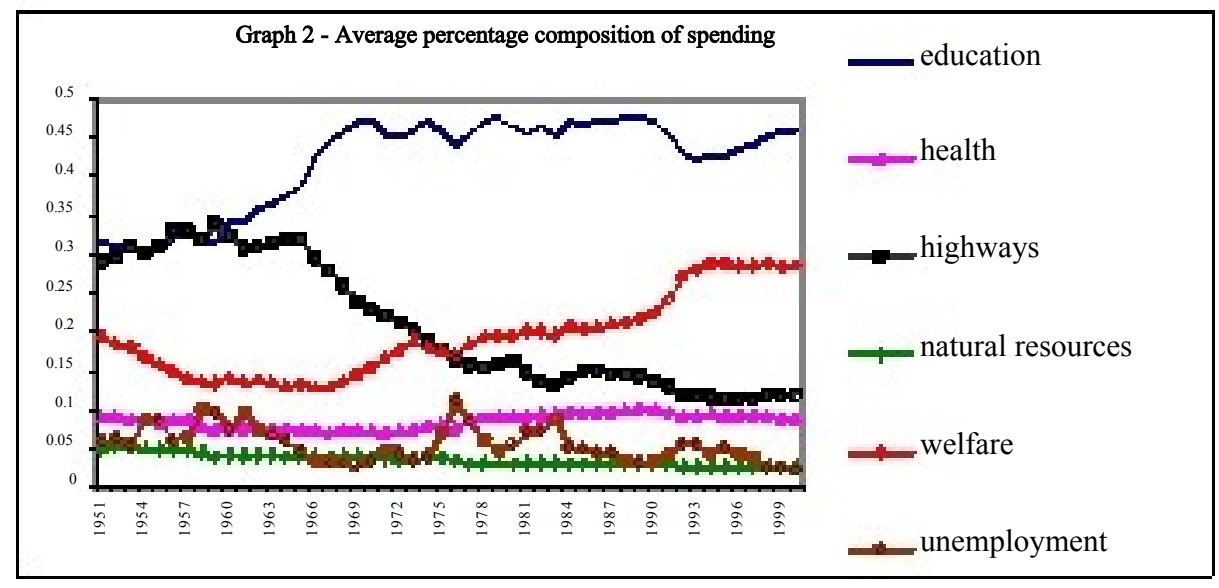

Although the overall level of tax collection would provide some indication on the state's ability to raise revenue through the cycle (which is likely to be inversely correlated with the necessity of maintaining savings and hence a potential determinant of BSF structure) the intended use of this variable here, however, is not to provide us with a measure of the wealth or fiscal capacity of the state. Firstly, tax collections would provide a flow -rather than stockindicator and would be in that sense inadequate for our purposes. Additionally, revenue collected through taxes yearly is likely to be highly correlated with other explanatory variables in our analysis (such as personal income and tax effort). As with spending, we include tax collection by grouping the different types of taxes (individual and corporate income tax, property, sales and severance taxes) according to their levels of volatility ${ }^{68}$. Graph 2 depicts the evolution of each tax's share over the period.

Tax collections has been a decreasingly important source of income for states, ${ }^{69}$ but still is the most important: According to data from the US Census of Governments, tax revenue and intergovernmental (IG) revenue together accounted for about $70 \%$ of all state resources in 2001. IG revenues include local and federal transfers (with the latter making about $95 \%$ of the total ${ }^{70}$ ) and are mostly outside of state control. They have grown in importance during our period of observation, although not steadily: In particular, and more importantly for our

variability), but the series become stationary after detrending it with the augmented Hodrick-Prescott filter making $\beta$ an indicator of the short-run variability over the sample period.

${ }^{68}$ The percentages of tax income that come from severance and property taxes are grouped in the "most volatile" category, while the percentages received from sale and individual income taxes form the "least volatile" category. The percentage of tax revenues derived from corporate income taxes corresponds to the "middle volatility" group, which is used as baseline.

${ }^{69}$ Dropping from about $70 \%$ in 1950 to around $60 \%$ in 2000 .

${ }^{70}$ As opposed to IG expenses, where local IG spending makes for most of the total expenditure. 
purposes, IG revenues are likely to decrease during periods of crises, when states need resources the most. IG finances are included in the analysis by calculating the deviation from the national mean of the per capita net IG transfers (revenues minus expenses).

All data on state tax collection, expenditure and IG finances come from the Census of Governments and the Historical Statistics of the United States. ${ }^{71}$

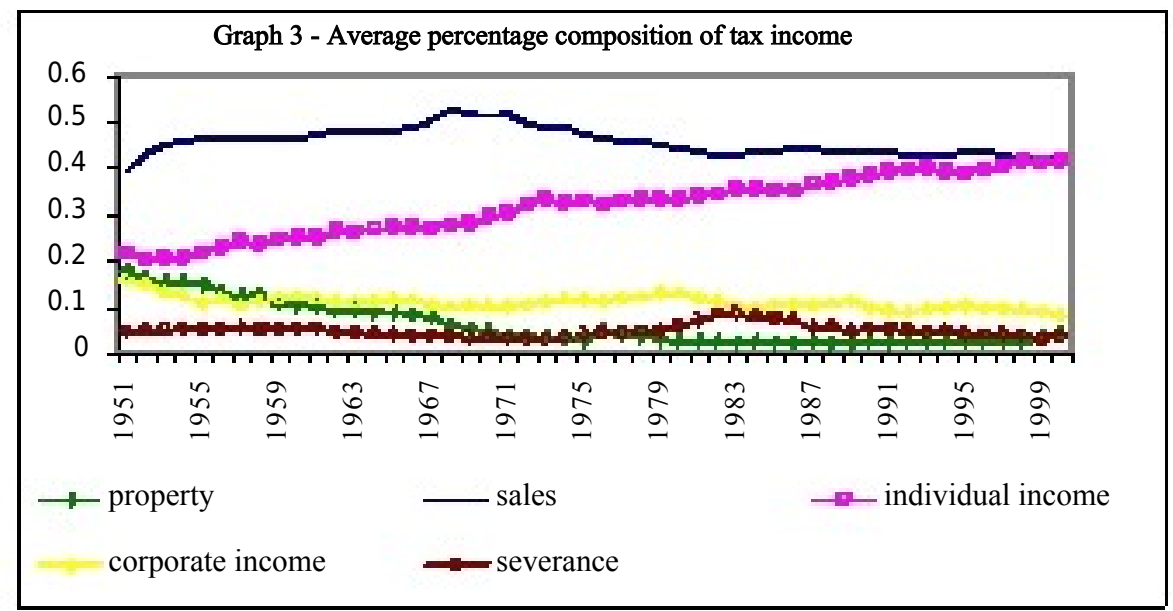

Although funds in BSFs are subject to rules that do not apply to other forms of savings, it is likely that states that maintain easily liquefiable resources (such as cash, short-term deposits and securities ${ }^{72}$ ) in larger amounts will see the need to establish a stringent fund as less pressing. On the other hand, it may be possible that states that decide to have more savings in the form of cash and securities have a preference for sound savings, and would be more inclined to establish strict funds. Since it is difficult to intuitively or theoretically establish a predicted sign for the relationship between other savings and the nature of BSFs, it remains a question best answered empirically. The Census only provides data for cash and securities (our measure of other savings) since 1951, imposing the lower time bound for the analysis. Other potential measures of state savings exist in the literature exist. For example, savings haven been measured using data on general fund balances from the National Association of State Budget Officers (NASBO), but consistent data are not available until rather recently (Hou

71 The data series for Alaska and Hawaii start in 1957 and 1955, respectively, due to their late incorporation to the Union.

${ }^{72}$ Examples of items that are (or are not) included in this item can be found in chapter 10 (Cash and Security Holdings) of the Census' Federal, State, and Local Governments Government Finance and Employment Classification Manual 
(2004)). Wagner (2003), among others, calculates savings as current revenues minus current expenditures using Census Data, an approach we have also explored ${ }^{73}$ - keeping in mind that the Census discourages this use. ${ }^{74}$ However, not-spent revenue may not be available for budget stabilization and, as Gold (1995) indicates, fungible resources available to the state are perhaps the best indicator of the means a state can count on to face a recession, suggesting that cash holdings may be a better measure for our purposes.

Aside from using reserves, states can increase the resources they derive from taxation. However, states that exert higher levels of tax effort will have less room for tax increases, making meaningful BSFs more attractive. We include information on average tax effort (measured as the ratio of actual tax revenue to the tax revenue that would be collected under a hypothetical, uniform tax system) using data provided by the Advisory Commission of Intergovernmental Relations (ACIR). ${ }^{75}$

On the other side of the spectrum, debt could potentially help weather recessions by smoothing out state consumption. Nevertheless, many states face restrictions in their capability to issue debt or require voter approval to issue guaranteed debt. Furthermore, debt is costly for states because it increases the future financial burden and may trigger increases in the future costs of borrowing if rating agencies are not satisfied with the state's amount of savings. There are several potential ways to include the effect of debt on the choice of BSF configuration, such as the amount of interest paid on debt from the Census data (to approximate the effective weight of accumulated debt in the budget), the ratio of total debt to personal income or a set of indicators for the limitations on the emission of debt. We settle for

${ }^{73}$ In particular, I calculated the deviation from the national average per capita savings. Using this indicator, we find some weak evidence that states with more savings are less likely to establish strict BSFs.

74 "Although the original sources of data for these finance statistics are the accounting records of governments, the data derived from them are purely statistical in nature and cannot be used as financial statements or to measure a government's fiscal condition. For instance, the difference between a government's total revenue and expenditure cannot be construed to be a "surplus" or "deficit."' Census' Government Finance and Employment Classification Manual, Chapter 6 (Overview of Government Finance Statistics.)

${ }^{75}$ ACIR only reports data for years 1967, 1975, 1977, 1979 and 1980 - 1988. Robert Tannenwald from the Federal Reserve of Boston has calculated tax effort for additional years using methodology based on ACIR's. Since inclusion of his data did not significantly affect the results and to avoid introducing differences in the tax effort series due to changes in methodology we restrict ourselves to the data provided by ACIR, which is the measure commonly used in the BSF literature. Additionally, the Tax Foundation calculates measures of state and local tax effort since 1970, however, it is impossible to separate the state component from their numbers so their data is not used in this application. 
using annual deviations from the national mean of total debt per capita ${ }^{76}$ because they are more likely to reflect the real situation of the state in terms of debt than the institutional constraints, which can be avoided in a variety of ways. ${ }^{77}$ Our a priori expectation is that states with higher levels of debt will be, ceteris paribus, more inclined to establish demanding BSFs, since they it would be relatively more costly for them to go further into debt. However, high levels of per capita debt may be correlated with higher tolerance for debt in the state, which could overcome the aforementioned effect. The final effect of indebtness on BSF rules is then left to empirical investigation.

Among the institutional constraints, tax and expenditure limitations (TELs) restrict the state's ability to cope with recessions through direct action, ${ }^{78}$ which may make meaningful BSFs more attractive. On the other hand, RDFs may be seen as a way to put funds outside of the scope of the TELs, allowing for higher discretion in the spending decisions, a proposition for which Wagner and Sobel (2006) find supporting evidence. We have explored different alternative measures of TELs, using dummies for the existence of each of these limitations as well as Poulson's (2005) indexes of TEL strictness. ${ }^{79}$

Another important institutional constraint is given by the existence of balanced budget requirements (BBR). States with demanding BBRs enact more restrictive spending policies (Poterba (1994)), fare better in deficit control (Alesina and Bayoumi (1996)), are more likely to enact tax increases and spending cuts during recessions (Alt and Lowry (1994)) and tend to save more (Bohn and Inman (1996)), but strict BBRs also introduce rigidities in fiscal policy

\footnotetext{
${ }^{76} \mathrm{We}$ also tried the deviation from the national mean of the state's ratio of debt to personal income and the results and find some scattered indications that states with higher deviations may be more likely to establish stricter deposit (although not withdrawal) rules.

77 A wide literature exists regarding the potential effects of debt restrictions on debt emissions. An interesting suggestion from this literature is that debt limits may have had one of its more important effects on the way states emit debt rather than on how much total debt is actually issued.

${ }^{78}$ Different views exist on the issue: Elder (1992) finds that TELs are associated with a significant decline in state tax revenues, while Poterba (1996) concludes that TEL-states deal more quickly with deficits by raising taxes.

79 Poulson (2005) creates indexes that consider the overall strictness of he TEL, whether voter approval is required for certain actions, what part of the budget is covered by the limits, the method of approval of the limitation and the treatment of surpluses. Of these, only the indicator regarding what part of the budget is covered by the TEL seems to have significant effects on the configuration of the BSF. In particular, there seems to be some evidence that the more demanding this feature of the TEL, the more likely states are to establish weak deposit requirements, although no effect is found on the determination of withdrawal rules.
} 
(Alt and Lowry (2001)) and may exacerbate business cycle volatility (Levinson (1998)).

Demanding BBRs make meaningful BSFs more appealing, since intertemporal smoothing becomes more difficult. All states (save Vermont) have a BBR, although the rules differ in their degree of stringency. We consider the same measure the literature has used: the index constructed by ACIR ${ }^{80}$ (1987) and the dummies NASBO derived from it; and, additionally, we follow Poterba (1994) in constructing a binary indicator to classify BBRs as "lax" or "strict."81 However, we deviate from the literature by correcting the data for Tennessee's BBR. ${ }^{82}$

The last institutional factor is embedded in the BSFs themselves. Their legal nature (statutory or constitutional) can also play a role on the configuration of deposit and withdrawal requirements. Constitutionally established BBRs and TELs are regarded as stricter budgetary tools, because they allow decision makers less freedom when establishing the particulars of the law and have been shown to have stronger effects on fiscal policy than their statutory counterparts. To investigate whether constitutional BSFs are more likely to be endowed with stricter requirements, we include a dummy that takes the value of one if the BSF is embedded in the state's Constitution.

\footnotetext{
${ }^{80}$ The index ranges from zero to ten, where higher numbers indicate stricter BBRs. It consideres the following order of (increasing) stringency: (1) rule requires governor to submit a balanced budget, (2) the legislature must pass a balanced budget, (3) carry-over of deficit is allowed to the next year but it must resolved within the following year, (4) deficit carry-over to the next biennium is not allowed, and (5) deficit carry-over to the next year is not allowed. Additionally, constitutional rules receive additional points.

${ }^{81}$ The advantage of using this binary indicator as opposed to the measure provided by ACIR is that it avoids giving the same relevance to unitary changes at all points in the scale while maintaining the difference between lax and strict rules for budget balancing. To investigate possible spurious effects brought about by the "border" cases, we run the regressions two more times, including all border cases (states that scored 5 or 6 in the ACIR index) first in the lower category and then in the upper category. ${ }^{82}$ ACIR reported Tennessee's BBR as it existed in 1987, but users of these data have often ignored the fact that Tennessee's history regarding balanced budgets -unlike the other states- included a change in the regulation. In particular, Tennessee did not have a BBR prior to 1978, when it adopted the ACIRreported BBR. This becomes especially important for studies like this one, which concern themselves with the set of circumstances that led to the adoption of BSFs, because Tennessee adopted its fund in 1972 -which means that using the ACIR index of 10 to measure Tennessee's BBR overstates the strictness of the rule in the years prior to the adoption of the fund.
} 
Table 1. Dates of adoption of states' Budget Stabilization Funds

\begin{tabular}{|c|c|c|c|c|c|}
\hline State & $\begin{array}{l}\text { Year of } \\
\text { adoption }\end{array}$ & State & $\begin{array}{l}\text { Year of } \\
\text { adoption }\end{array}$ & State & $\begin{array}{l}\text { Year of } \\
\text { adoption }\end{array}$ \\
\hline Alabama & . & Louisiana & 1990 & Ohio & 1981 \\
\hline Alaska & 1986 & Maine & 1985 & Oklahoma & 1985 \\
\hline Arizona & 1990 & Maryland & 1986 & Oregon & . \\
\hline Arkansas & . & Massachusetts & 1986 & Pennsylvania & 1985 \\
\hline California & 1985 & Michigan & 1977 & Rhode Island & 1985 \\
\hline Colorado & . & Minnesota & 1981 & South Carolina & 1978 \\
\hline Connecticut & 1979 & Mississippi & 1982 & South Dakota & 1991 \\
\hline Delaware & 1977 & Missouri & 1992 & Tennessee & 1972 \\
\hline Florida & 1959 & Montana & . & Texas & 1987 \\
\hline Georgia & 1976 & Nebraska & 1983 & Utah & 1986 \\
\hline Hawaii & 2000 & Nevada & 1994 & Vermont & 1988 \\
\hline Idaho & 1984 & New Hampshire & 1987 & Virginia & 1992 \\
\hline Illinois & 2000 & New Jersey & 1990 & Washington & 1981 \\
\hline Indiana & 1982 & New Mexico & 1978 & West Virginia & 1994 \\
\hline Iowa & 1992 & New York & 1945 & Wisconsin & 1981 \\
\hline Kansas & 1993 & North Carolina & 1991 & Wyoming & 1982 \\
\hline Kentucky & 1983 & North Dakota & 1987 & & \\
\hline
\end{tabular}

Notes: "." indicates the state does not have a BSF.

Source: Wagner (2004) and documents for the state of Colorado 
Table 2- Deposit and withdrawal requirements in the BSFs

\begin{tabular}{|c|c|c|c|c|c|c|c|}
\hline \multicolumn{4}{|c|}{ Deposit requirements } & \multicolumn{4}{|c|}{ Withdrawal requirements } \\
\hline Alabama & . & Montana & $\cdot$ & Alabama & . & Montana & 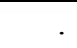 \\
\hline Alaska & 1 & Nebraska & 2 & Alaska & 1 & Nebraska & 2 \\
\hline Arizona & 4 & Nevada & 4 & Arizona & 4 & Nevada & 2 \\
\hline Arkansas & . & New Hampshire & 2 & Arkansas & . & New Hampshire 2 & 2 \\
\hline California & 2 & New Jersey & 2 & California & 2 & New Jersey & 2 \\
\hline Colorado & . & New Mexico & 2 & Colorado & . & New Mexico & 1 \\
\hline Connecticut & 2 & New York & 4 & Connecticut & 3 & New York & 2 \\
\hline Delaware & 2 & North Carolina & 2 & Delaware & 3 & North Carolina & 1 \\
\hline Florida & 2 & North Dakota & 2 & Florida & 2 & North Dakota & 4 \\
\hline Georgia & 2 & Ohio & 2 & Georgia & 1 & Ohio & 1 \\
\hline Hawaii & 1 & Oklahoma & 2 & Hawaii & 3 & Oklahoma & 3 \\
\hline Idaho* & 1 & Oregon & . & Idaho* & 3 & Oregon & . \\
\hline Illinois & 2 & Pennsylvania & 2 & Illinois & 1 & Pennsylvania & 3 \\
\hline Indiana & 4 & Rhode Island & 1 & Indiana & 4 & Rhode Island & 2 \\
\hline Iowa & 1 & South Carolina & 3 & Iowa & 1 & South Carolina & 2 \\
\hline Kansas & 3 & South Dakota & 2 & Kansas & 1 & South Dakota & 2 \\
\hline Kentucky & 2 & Tennessee & 3 & Kentucky & 1 & Tennessee & 2 \\
\hline Louisiana & 2 & Texas & 2 & Louisiana & 1 & Texas & 2 \\
\hline Maine & 2 & Utah & 2 & Maine & 1 & Utah & 2 \\
\hline Maryland & 3 & Vermont & 2 & Maryland & 1 & Vermont & 2 \\
\hline Massachuset & & Virginia & 4 & Massachusetts & 1 & Virginia & 4 \\
\hline Michigan & 4 & Washington & 2 & Michigan & 4 & Washington & 3 \\
\hline Minnesota & 1 & West Virginia & 2 & Minnesota & 1 & West Virginia & 2 \\
\hline Mississippi & 1 & Wisconsin & 3 & Mississippi & 1 & Wisconsin & 2 \\
\hline Missouri & 1 & Wyoming & 1 & Missouri & 1 & Wyoming & 1 \\
\hline
\end{tabular}

Deposit requirements: (1) appropriation (2) genera fund surplus (3) required appropriation (4) formula

Withdrawal requirements: (1) appropriation (2) revenue shortfall (3) supermajority required (4) formula

* Idaho modified its BSF in 1999, making it stricter. Here we record the original requirements as they were established when the BSF was adopted in 1981.

Source: Wagner (2004) and documents of the state of Colorado. 
Table 3. Ordered logits. Dependent variable: deposit requirement

\begin{tabular}{|c|c|c|c|c|c|c|c|c|}
\hline Description of independent variables & weak & strict & weak & strict & weak & strict & weak & strict \\
\hline Number of seats in upper House & $8.55 \mathrm{E}-05 * * *$ & $2.51 \mathrm{E}-05 * * *$ & & & & & & \\
\hline Number of seats in lower House & $-5.56 \mathrm{E}-06$ & $-1.63 \mathrm{E}-06$ & & & & & & \\
\hline$\%$ seat gap between main parties (Upper House) & & & $2.62 \mathrm{E}-05$ & 8.07E-06 & $2.28 \mathrm{E}-05$ & 7.02E-06 & $3.44 \mathrm{E}-05$ & $1.06 \mathrm{E}-05$ \\
\hline$\%$ seat gap between main parties (Lower House) & & & $-1.29 \mathrm{E}-04$ & $-3.98 \mathrm{E}-05$ & $-1.30 \mathrm{E}-04$ & $-3.98 \mathrm{E}-05$ & $-1.24 \mathrm{E}-04$ & $-3.80 \mathrm{E}-05$ \\
\hline Democratic Governor & & & & & & & $-1.26 \mathrm{E}-03$ & $-3.88 \mathrm{E}-04$ \\
\hline Appointed Supreme Court & & & & & $-1.74 \mathrm{E}-03$ & $-5.33 \mathrm{E}-04$ & & \\
\hline Limit for governor's tenancy & & & & & & & $-3.02 \mathrm{E}-03$ & $-9.28 \mathrm{E}-04$ \\
\hline Deviation from average per capita personal income & $-1.06 \mathrm{E}-06$ & $-3.10 \mathrm{E}-07$ & $-1.88 \mathrm{E}-06$ & $-5.80 \mathrm{E}-07$ & $-1.90 \mathrm{E}-06$ & $-5.83 \mathrm{E}-07$ & $-1.93 \mathrm{E}-06$ & $-5.94 \mathrm{E}-07$ \\
\hline Percentage of earnings - farming & $-6.56 \mathrm{E}-02 * *$ & $-1.92 \mathrm{E}-02 * *$ & $-5.55 \mathrm{E}-02 *$ & $-1.71 \mathrm{E}-02 *$ & $-5.67 \mathrm{E}-02 * *$ & $-1.74 \mathrm{E}-02 * *$ & $-5.93 \mathrm{E}-02 * *$ & $-1.82 \mathrm{E}-02 * *$ \\
\hline Percentage of earnings - construction & $-1.09 \mathrm{E}-01 *$ & $-3.19 \mathrm{E}-02 *$ & $-9.70 \mathrm{E}-02 *$ & $-2.99 \mathrm{E}-02 *$ & $-9.00 \mathrm{E}-02 *$ & $-2.77 \mathrm{E}-02 *$ & $-1.04 \mathrm{E}-01 * *$ & $-3.20 \mathrm{E}-02 * *$ \\
\hline Percentage of earnings - manufacturing & $-3.73 \mathrm{E}-02 *$ & $-1.09 \mathrm{E}-02 *$ & $-3.25 \mathrm{E}-02 *$ & $-1.00 \mathrm{E}-02 *$ & $-3.19 \mathrm{E}-02 *$ & $-9.81 \mathrm{E}-03 *$ & $-3.63 \mathrm{E}-02 * *$ & $-1.12 \mathrm{E}-02 * *$ \\
\hline Percentage of earnings - mining & $-4.44 \mathrm{E}-02$ & $-1.30 \mathrm{E}-02$ & $-3.53 \mathrm{E}-02$ & $-1.09 \mathrm{E}-02$ & $-3.83 \mathrm{E}-02$ & $-1.18 \mathrm{E}-02$ & $-3.77 \mathrm{E}-02$ & $-1.16 \mathrm{E}-02$ \\
\hline Percentage of tax revenue - most volatile & $-1.64 \mathrm{E}-02$ & $-4.81 \mathrm{E}-03$ & $-5.53 \mathrm{E}-03$ & $-1.70 \mathrm{E}-03$ & $-7.57 \mathrm{E}-03$ & $-2.33 \mathrm{E}-03$ & $-7.44 \mathrm{E}-03$ & $-2.28 \mathrm{E}-03$ \\
\hline Percentage of tax revenue - least volatile & $-2.09 \mathrm{E}-02$ & $-6.13 \mathrm{E}-03$ & $-1.64 \mathrm{E}-02$ & $-5.04 \mathrm{E}-03$ & $-1.69 \mathrm{E}-02$ & $-5.20 \mathrm{E}-03$ & $-1.51 \mathrm{E}-02$ & $-4.62 \mathrm{E}-03$ \\
\hline Percentage of expenditure - most volatile & $8.14 \mathrm{E}-02 * * *$ & $2.39 \mathrm{E}-02 * * *$ & $8.13 \mathrm{E}-02 * * *$ & $2.50 \mathrm{E}-02 * * *$ & $7.80 \mathrm{E}-02 * * *$ & $2.40 \mathrm{E}-02 * * *$ & $7.83 \mathrm{E}-02 * * *$ & $2.40 \mathrm{E}-02 * * *$ \\
\hline Percentage of expenditure - least volatile & $6.58 \mathrm{E}-03$ & $1.93 \mathrm{E}-03$ & $1.07 \mathrm{E}-02$ & $3.30 \mathrm{E}-03$ & 7.49E-03 & $2.30 \mathrm{E}-03$ & $1.43 \mathrm{E}-02$ & $4.40 \mathrm{E}-03$ \\
\hline Deviation from average per capita savings & $1.28 \mathrm{E}+00$ & $3.76 \mathrm{E}-01$ & $8.40 \mathrm{E}-01$ & $2.59 \mathrm{E}-01$ & $8.95 \mathrm{E}-01$ & $2.75 \mathrm{E}-01$ & $6.78 \mathrm{E}-01$ & $2.08 \mathrm{E}-01$ \\
\hline Tax effort & $2.30 \mathrm{E}-05$ & $6.75 \mathrm{E}-06$ & $9.24 \mathrm{E}-06$ & 2.85E-06 & $2.09 \mathrm{E}-05$ & 6.43E-06 & $-4.96 \mathrm{E}-05$ & $-1.53 \mathrm{E}-05$ \\
\hline Expenditure limitation & $5.00 \mathrm{E}-03$ & $1.47 \mathrm{E}-03$ & $5.49 \mathrm{E}-03$ & $1.70 \mathrm{E}-03$ & $6.02 \mathrm{E}-03$ & $1.86 \mathrm{E}-03$ & $4.19 \mathrm{E}-03$ & $1.29 \mathrm{E}-03$ \\
\hline BBR stringency & $-5.30 \mathrm{E}-05$ & $-1.55 \mathrm{E}-05$ & $2.34 \mathrm{E}-05$ & 7.21E-06 & 7.41E-05 & $2.28 \mathrm{E}-05$ & $1.96 \mathrm{E}-04$ & $6.02 \mathrm{E}-05$ \\
\hline Deviation from average per capita debt & $-7.54 \mathrm{E}-06$ & $-2.21 \mathrm{E}-06$ & $-4.22 \mathrm{E}-06$ & $-1.30 \mathrm{E}-06$ & $-4.61 \mathrm{E}-06$ & $-1.42 \mathrm{E}-06$ & $-3.55 \mathrm{E}-06$ & $-1.09 \mathrm{E}-06$ \\
\hline Population density & $1.15 \mathrm{E}-06$ & $3.39 \mathrm{E}-07$ & $5.08 \mathrm{E}-06$ & $1.57 \mathrm{E}-06$ & $6.00 \mathrm{E}-06$ & $1.84 \mathrm{E}-06$ & 5.92E-06 & $1.82 \mathrm{E}-06$ \\
\hline Constitutional BSF & $6.15 \mathrm{E}-03$ & $1.82 \mathrm{E}-03$ & $6.77 \mathrm{E}-03$ & $2.10 \mathrm{E}-03$ & $7.70 \mathrm{E}-03$ & $2.39 \mathrm{E}-03$ & 7.43E-03 & $2.30 \mathrm{E}-03$ \\
\hline Deviation from average per capita net IG revenue & $1.32 \mathrm{E}-02$ & $3.86 \mathrm{E}-03$ & 7.18E-03 & $2.21 \mathrm{E}-03$ & $8.88 \mathrm{E}-03$ & $2.73 \mathrm{E}-03$ & $7.26 \mathrm{E}-03$ & $2.23 \mathrm{E}-03$ \\
\hline$\overline{\text { Log Likelihood }}$ & \multicolumn{2}{|c|}{-182.09951} & \multicolumn{2}{|c|}{-179.69465} & \multicolumn{2}{|c|}{-179.55244} & \multicolumn{2}{|c|}{-178.95421} \\
\hline
\end{tabular}

*** Significant at $1 \%, * *$ Significant at $5 \%, *$ Significant at $10 \%$

The dependent variable equals zero in years prior to BSF adoption, in the year of adoption it equals 1 if the adopted deposit requirement is lax and 2 if it is strict 
Table 4. Ordered logits. Dependent variable: withdrawal requirement

\begin{tabular}{|c|c|c|c|c|c|c|c|c|}
\hline Description of independent variables & weak & strict & weak & strict & weak & strict & weak & strict \\
\hline Number of seats in upper House & $8.63 \mathrm{E}-05^{* * *}$ & $2.53 \mathrm{E}-05 * * *$ & & & & & & \\
\hline Number of seats in lower House & $-5.19 \mathrm{E}-06$ & $-1.52 \mathrm{E}-06$ & & & & & & \\
\hline$\%$ seat gap between main parties (Upper House) & & & $1.88 \mathrm{E}-05$ & $5.74 \mathrm{E}-06$ & $1.43 \mathrm{E}-05$ & $4.36 \mathrm{E}-06$ & $2.88 \mathrm{E}-05$ & $8.80 \mathrm{E}-06$ \\
\hline$\%$ seat gap between main parties (Lower House) & & & $-1.36 \mathrm{E}-04$ & $-4.16 \mathrm{E}-05$ & $-1.36 \mathrm{E}-04$ & $-4.15 \mathrm{E}-05$ & $-1.30 \mathrm{E}-04$ & $-3.98 \mathrm{E}-05$ \\
\hline Democratic Governor & & & & & & & $-1.40 \mathrm{E}-03$ & $-4.28 \mathrm{E}-04$ \\
\hline Appointed Supreme Court & & & & & $-2.16 \mathrm{E}-03$ & $-6.57 \mathrm{E}-04$ & & \\
\hline Limit for governor's tenancy & & & & & & & $-2.91 \mathrm{E}-03$ & $-8.87 \mathrm{E}-04$ \\
\hline Deviation from average per capita personal income & $-1.16 \mathrm{E}-06$ & $-3.41 \mathrm{E}-07$ & $-2.09 \mathrm{E}-06$ & $-6.38 \mathrm{E}-07$ & $-2.11 \mathrm{E}-06$ & $-6.42 \mathrm{E}-07$ & $-2.11 \mathrm{E}-06$ & $-6.44 \mathrm{E}-07$ \\
\hline Percentage of earnings - farming & $-6.53 \mathrm{E}-02 *$ & $-1.91 \mathrm{E}-02 *$ & $-5.41 \mathrm{E}-02 *$ & $-1.66 \mathrm{E}-02 *$ & $-5.57 \mathrm{E}-02 *$ & $-1.70 \mathrm{E}-02 *$ & $-5.77 \mathrm{E}-02 *$ & $-1.76 \mathrm{E}-02 *$ \\
\hline Percentage of earnings - construction & $-1.13 \mathrm{E}-01 *$ & $-3.30 \mathrm{E}-02 *$ & $-1.00 \mathrm{E}-01 *$ & $-3.07 \mathrm{E}-02 *$ & $-9.16 \mathrm{E}-02 *$ & $-2.79 \mathrm{E}-02 *$ & $-1.06 \mathrm{E}-01 *$ & $-3.23 \mathrm{E}-02 *$ \\
\hline Percentage of earnings - manufacturing & $-3.80 \mathrm{E}-02 *$ & $-1.11 \mathrm{E}-02 *$ & $-3.32 \mathrm{E}-02 *$ & $-1.01 \mathrm{E}-02 *$ & $-3.25 \mathrm{E}-02 *$ & $-9.91 \mathrm{E}-03 *$ & $-3.70 \mathrm{E}-02 *$ & $-1.13 \mathrm{E}-02 *$ \\
\hline Percentage of earnings - mining & $-4.62 \mathrm{E}-02$ & $-1.35 \mathrm{E}-02$ & $-3.69 \mathrm{E}-02 *$ & $-1.13 \mathrm{E}-02 *$ & $-4.11 \mathrm{E}-02$ & $-1.25 \mathrm{E}-02$ & $-3.95 \mathrm{E}-02$ & $-1.20 \mathrm{E}-02$ \\
\hline Percentage of tax revenue - most volatile & $-1.48 \mathrm{E}-02$ & $-4.32 \mathrm{E}-03$ & $-2.70 \mathrm{E}-03$ & $-8.24 \mathrm{E}-04$ & $-4.99 \mathrm{E}-03$ & $-1.52 \mathrm{E}-03$ & $-4.82 \mathrm{E}-03$ & $-1.47 \mathrm{E}-03$ \\
\hline Percentage of tax revenue - least volatile & $-1.48 \mathrm{E}-02$ & $-4.32 \mathrm{E}-03$ & $-1.63 \mathrm{E}-02$ & $-5.00 \mathrm{E}-03$ & $-1.70 \mathrm{E}-02$ & $-5.18 \mathrm{E}-03$ & $-1.51 \mathrm{E}-02$ & $-4.62 \mathrm{E}-03$ \\
\hline Percentage of expenditure - most volatile & $8.20 \mathrm{E}-02 * * *$ & $2.40 \mathrm{E}-02 * * *$ & $8.08 \mathrm{E}-02 * * *$ & $2.47 \mathrm{E}-02 * * *$ & $7.67 \mathrm{E}-02 * * *$ & $2.34 \mathrm{E}-02 * * *$ & $.81 \mathrm{E}-02 * * *$ & $2.38 \mathrm{E}-02 * * *$ \\
\hline Percentage of expenditure - least volatile & $5.34 \mathrm{E}-03$ & $1.56 \mathrm{E}-03$ & $9.14 \mathrm{E}-03$ & $2.79 \mathrm{E}-03$ & $5.36 \mathrm{E}-03$ & $1.63 \mathrm{E}-03$ & $1.30 \mathrm{E}-02$ & $3.98 \mathrm{E}-03$ \\
\hline Deviation from average per capita savings & $1.22 \mathrm{E}+00$ & $3.57 \mathrm{E}-01$ & $6.81 \mathrm{E}-01$ & $2.08 \mathrm{E}-01$ & 7.42E-01 & $2.26 \mathrm{E}-01$ & $5.38 \mathrm{E}-01$ & 1.64E-01 \\
\hline Tax effort & $2.26 \mathrm{E}-05$ & $6.62 \mathrm{E}-06$ & $6.46 \mathrm{E}-06$ & $1.98 \mathrm{E}-06$ & 2.07E-05 & $6.31 \mathrm{E}-06$ & $-4.92 \mathrm{E}-05$ & $-1.50 \mathrm{E}-05$ \\
\hline Expenditure limitation & $5.41 \mathrm{E}-03$ & $1.59 \mathrm{E}-03$ & $6.26 \mathrm{E}-03$ & $1.93 \mathrm{E}-03$ & $6.97 \mathrm{E}-03$ & $2.14 \mathrm{E}-03$ & 4.77E-03 & $1.46 \mathrm{E}-03$ \\
\hline BBR stringency & $-5.60 \mathrm{E}-05$ & $-1.64 \mathrm{E}-05$ & $2.48 \mathrm{E}-05$ & $7.60 \mathrm{E}-06$ & $8.78 \mathrm{E}-05$ & $2.67 \mathrm{E}-05$ & $1.94 \mathrm{E}-04$ & 5.92E-05 \\
\hline Deviation from average per capita debt & $-7.18 \mathrm{E}-06 *$ & $-2.10 \mathrm{E}-06 *$ & $-3.56 \mathrm{E}-06 *$ & $-1.09 \mathrm{E}-06 *$ & $-4.07 \mathrm{E}-06 *$ & $-1.24 \mathrm{E}-06 *$ & $-2.94 \mathrm{E}-06$ & $-8.96 \mathrm{E}-07$ \\
\hline Population density & 1.24E-06 & $3.62 \mathrm{E}-07$ & $5.68 \mathrm{E}-06$ & $1.74 \mathrm{E}-06$ & $6.81 \mathrm{E}-06$ & $2.08 \mathrm{E}-06$ & $6.47 \mathrm{E}-06$ & $1.97 \mathrm{E}-06$ \\
\hline Constitutional BSF & $6.27 \mathrm{E}-03$ & $1.85 \mathrm{E}-03$ & 7.41E-03 & $2.28 \mathrm{E}-03$ & $6.81 \mathrm{E}-06$ & $2.08 \mathrm{E}-06$ & $7.88 \mathrm{E}-03$ & $2.43 \mathrm{E}-03$ \\
\hline Deviation from average per capita net IG revenue & $1.38 \mathrm{E}-02$ & 4.03E-03 & $8.26 \mathrm{E}-03$ & $2.53 \mathrm{E}-03$ & $1.04 \mathrm{E}-02$ & $3.17 \mathrm{E}-03$ & $8.18 \mathrm{E}-03$ & $2.49 \mathrm{E}-03$ \\
\hline Log Likelihood & \multicolumn{2}{|c|}{-182.0834} & \multicolumn{2}{|c|}{-179.35376} & \multicolumn{2}{|c|}{-179.13407} & \multicolumn{2}{|c|}{-178.61558} \\
\hline
\end{tabular}

*** Significant at $1 \%, * *$ Significant at $5 \%, *$ Significant at $10 \%$

The dependent variable equals zero in years prior to BSF adoption, in the year of adoption it equals 1 if the adopted withdrawal requirement is lax and 2 if it is strict 
Table 5. Multinomial logits. Dependent variable: deposit requirement

\begin{tabular}{|c|c|c|c|c|c|c|c|c|}
\hline Description of independent variables & weak & strict & weak & strict & weak & strict & weak & strict \\
\hline Number of seats in upper House & $3.79 \mathrm{E}-04 * *$ & $-8.41 \mathrm{E}-11$ & & & & & & \\
\hline Number of seats in lower House & $3.87 \mathrm{E}-06$ & $-3.09 \mathrm{E}-11 *$ & & & & & & \\
\hline$\%$ seat gap between main parties (Upper House) & & & $-1.20 \mathrm{E}-06$ & $6.94 \mathrm{E}-11$ & $-5.17 \mathrm{E}-06$ & $9.09 \mathrm{E}-12$ & $9.47 \mathrm{E}-06$ & $3.46 \mathrm{E}-11$ \\
\hline$\%$ seat gap between main parties (Lower House) & & & $-1.23 \mathrm{E}-04$ & $-9.74 \mathrm{E}-11$ & $-1.26 \mathrm{E}-04$ & $-9.77 \mathrm{E}-12$ & $-1.10 \mathrm{E}-04$ & $-4.98 \mathrm{E}-11 *$ \\
\hline Democratic Governor & & & & & & & $-2.34 \mathrm{E}-03$ & $-2.33 \mathrm{E}-10$ \\
\hline Appointed Supreme Court & & & & & $-2.98 \mathrm{E}-03$ & $1.29 \mathrm{E}-09 *$ & & \\
\hline Deviation from average per capita personal income & $-7.53 \mathrm{E}-07$ & $-1.40 \mathrm{E}-13$ & $-1.67 \mathrm{E}-06$ & $-1.16 \mathrm{E}-12$ & $-1.62 \mathrm{E}-06$ & $-1.15 \mathrm{E}-13$ & $-1.73 \mathrm{E}-06$ & $-5.16 \mathrm{E}-13$ \\
\hline Percentage of earnings - farming & $-3.73 \mathrm{E}-02 *$ & $-5.73 \mathrm{E}-08$ & $-2.17 \mathrm{E}-02$ & $-1.39 \mathrm{E}-07 * * *$ & $-2.44 \mathrm{E}-02$ & $-1.26 \mathrm{E}-08 * * *$ & $-2.58 \mathrm{E}-02$ & $-6.59 \mathrm{E}-08 * * *$ \\
\hline Percentage of earnings - construction & $-4.39 \mathrm{E}-02$ & $-2.62 \mathrm{E}-08$ & $-5.00 \mathrm{E}-02$ & $-8.40 \mathrm{E}-08 *$ & $-3.71 \mathrm{E}-02$ & $-6.75 \mathrm{E}-09$ & $-5.46 \mathrm{E}-02$ & $-4.12 \mathrm{E}-08 *$ \\
\hline Percentage of earnings - manufacturing & $-2.78 \mathrm{E}-02$ & $2.86 \mathrm{E}-09$ & $-1.64 \mathrm{E}-02$ & $6.91 \mathrm{E}-10$ & $-1.50 \mathrm{E}-02$ & $1.08 \mathrm{E}-09$ & $-2.14 \mathrm{E}-02$ & $2.50 \mathrm{E}-10$ \\
\hline Percentage of earnings - mining & $-2.63 \mathrm{E}-03$ & $-6.12 \mathrm{E}-08 * *$ & $3.39 \mathrm{E}-03$ & $-9.80 \mathrm{E}-08 *$ & $-2.72 \mathrm{E}-04$ & $-6.01 \mathrm{E}-09$ & $-4.59 \mathrm{E}-04$ & $-4.36 \mathrm{E}-08$ \\
\hline Percentage of tax revenue - most volatile & $-2.51 \mathrm{E}-02$ & $5.75 \mathrm{E}-09$ & $-8.82 \mathrm{E}-03$ & $1.33 \mathrm{E}-08$ & $-1.20 \mathrm{E}-02$ & $2.59 \mathrm{E}-09$ & $-1.23 \mathrm{E}-02$ & 3.33E-09 \\
\hline Percentage of expenditure - most volatile & $7.35 \mathrm{E}-02 * *$ & $1.60 \mathrm{E}-08$ & $9.11 \mathrm{E}-02 * * *$ & $2.22 \mathrm{E}-08$ & 8.47E-02 $* * *$ & 4.31E-09 & $8.58 \mathrm{E}-02 * * *$ & $9.81 \mathrm{E}-09$ \\
\hline Percentage of expenditure - least volatile & $2.29 \mathrm{E}-02$ & $1.20 \mathrm{E}-08$ & $2.36 \mathrm{E}-02$ & $1.12 \mathrm{E}-08$ & $1.73 \mathrm{E}-02$ & 3.03E-09 & $3.16 \mathrm{E}-02$ & $4.12 \mathrm{E}-09$ \\
\hline Deviation from average per capita savings & $1.09 \mathrm{E}+00$ & $-9.08 \mathrm{E}-07$ & $6.24 \mathrm{E}-01$ & $-7.52 \mathrm{E}-07$ & $6.82 \mathrm{E}-01$ & $-1.94 \mathrm{E}-07$ & $3.97 \mathrm{E}-01$ & $-3.60 \mathrm{E}-07$ \\
\hline Tax effort & $-1.77 \mathrm{E}-04$ & $3.94 \mathrm{E}-11$ & $-1.35 \mathrm{E}-04 * *$ & $1.66 \mathrm{E}-10 * *$ & $1.15 \mathrm{E}-04 *$ & $1.29 \mathrm{E}-11 * *$ & $1.84 \mathrm{E}-04 * *$ & $8.81 \mathrm{E}-11 *$ \\
\hline Expenditure limitation & $9.01 \mathrm{E}-03$ & $-5.71 \mathrm{E}-11$ & 7.17E-03 & $1.89 \mathrm{E}-09$ & $8.12 \mathrm{E}-03$ & $1.20 \mathrm{E}-10$ & $5.41 \mathrm{E}-03$ & $9.10 \mathrm{E}-10$ \\
\hline BBR stringency & $1.49 \mathrm{E}-04$ & $-8.32 \mathrm{E}-10 * * *$ & $2.15 \mathrm{E}-04$ & $-2.34 \mathrm{E}-09 * * *$ & 2.91E-04 & $-2.83 \mathrm{E}-10 * * *$ & $3.81 \mathrm{E}-04$ & $-1.11 \mathrm{E}-09 * * *$ \\
\hline Deviation from average per capita debt & $-3.17 \mathrm{E}-06$ & $-6.35 \mathrm{E}-12 * * *$ & $4.00 \mathrm{E}-07$ & $-1.48 \mathrm{E}-11 * * *$ & $-9.88 \mathrm{E}-07$ & $-1.28 \mathrm{E}-12 * * *$ & 4.63E-07 & $-6.83 \mathrm{E}-12 * * *$ \\
\hline Population density & $4.31 \mathrm{E}-06$ & $-1.21 \mathrm{E}-11 * * *$ & $8.85 \mathrm{E}-06$ & $-2.92 \mathrm{E}-11 * * *$ & $1.04 \mathrm{E}-05$ & $-2.50 \mathrm{E}-12 * * *$ & $9.04 \mathrm{E}-06$ & $-1.46 \mathrm{E}-11 * * *$ \\
\hline Constitutional BSF & $-3.59 \mathrm{E}-03$ & $1.19 \mathrm{E}-05 * * *$ & $-3.15 \mathrm{E}-03$ & $8.39 \mathrm{E}-05 * * *$ & $-2.60 \mathrm{E}-03$ & $2.87 \mathrm{E}-06 * * *$ & $-2.33 \mathrm{E}-03$ & $6.38 \mathrm{E}-05 * * *$ \\
\hline Deviation from average per capita net IG revenue & $1.48 \mathrm{E}-02$ & $5.48 \mathrm{E}-09$ & $8.87 \mathrm{E}-03$ & $-6.48 \mathrm{E}-09$ & $1.16 \mathrm{E}-02$ & $-1.52 \mathrm{E}-09$ & $8.01 \mathrm{E}-03$ & $-3.23 \mathrm{E}-09$ \\
\hline Log Likelihood & \multicolumn{2}{|c|}{-153.05429} & \multicolumn{2}{|c|}{-155.28692} & \multicolumn{2}{|c|}{-153.23644} & \multicolumn{2}{|c|}{-154.11043} \\
\hline
\end{tabular}

*** Significant at $1 \%, * *$ Significant at $5 \%, *$ Significant at $10 \%$

The dependent variable equals zero in years prior to BSF adoption, in the year of adoption it equals 1 if the adopted deposit requirement is lax and 2 if it is strict 
Table 6. Multinomial logits. Dependent variable: withdrawal requirement

\begin{tabular}{|c|c|c|c|c|c|c|c|c|}
\hline Description of independent variables & weak & strict & weak & strict & weak & strict & weak & strict \\
\hline Number of seats in upper House & $2.77 \mathrm{E}-04 *$ & $4.23 \mathrm{E}-06$ & & & & & & \\
\hline Number of seats in lower House & $4.22 \mathrm{E}-06$ & $-4.04 \mathrm{E}-06$ & & & & & & \\
\hline$\%$ seat gap between main parties (Upper House) & & & $1.10 \mathrm{E}-04$ & $-1.35 \mathrm{E}-06$ & $1.06 \mathrm{E}-04$ & $-1.20 \mathrm{E}-06$ & $1.14 \mathrm{E}-04$ & $-4.51 \mathrm{E}-07$ \\
\hline$\%$ seat gap between main parties (Lower House) & & & $-1.01 \mathrm{E}-04$ & $-4.22 \mathrm{E}-06 * * *$ & $1.02 \mathrm{E}-04$ & $-3.62 \mathrm{E}-06 * * *-9$ & 26E-05 & $-1.69 \mathrm{E}-06 * * *$ \\
\hline Democratic Governor & & & & & & & $-1.19 \mathrm{E}-03$ & $-3.52 \mathrm{E}-05$ \\
\hline Appointed Supreme Court & & & & & $-1.45 \mathrm{E}-03$ & $-5.38 \mathrm{E}-05$ & & \\
\hline Deviation from average per capita personal income & $-1.13 \mathrm{E}-06$ & $-7.62 \mathrm{E}-08$ & $-9.52 \mathrm{E}-07$ & $-5.31 \mathrm{E}-08 *$ & $-9.60 \mathrm{E}-07$ & $-4.91 \mathrm{E}-08 *$ & $-1.02 \mathrm{E}-06$ & $-2.29 \mathrm{E}-08 *$ \\
\hline Percentage of earnings - farming & $-4.49 \mathrm{E}-02 *$ & $-1.28 \mathrm{E}-03$ & $-4.65 \mathrm{E}-02 *$ & $-1.61 \mathrm{E}-04$ & $-4.69 \mathrm{E}-02 *$ & $*-2.52 \mathrm{E}-04$ & $-5.24 \mathrm{E}-02$ & $-6.40 \mathrm{E}-05$ \\
\hline Percentage of earnings - construction & $-3.39 \mathrm{E}-02$ & $-1.22 \mathrm{E}-02 * * *$ & $-4.78 \mathrm{E}-02$ & $-3.65 \mathrm{E}-03 * * *$ & $4.35 \mathrm{E}-02$ & $-3.09 \mathrm{E}-03 * * *-6$ & $47 \mathrm{E}-02$ & $-1.34 \mathrm{E}-03$ \\
\hline Percentage of earnings - manufacturing & $-3.68 \mathrm{E}-02 *$ & $-8.53 \mathrm{E}-04$ & $-3.00 \mathrm{E}-02 *$ & $-3.55 \mathrm{E}-04$ & 2.97E-02* & $-3.17 \mathrm{E}-04$ & $-3.70 \mathrm{E}-02 * *$ & $-1.52 \mathrm{E}-04$ \\
\hline Percentage of earnings - mining & $-3.90 \mathrm{E}-03$ & $-6.70 \mathrm{E}-03$ & $-4.44 \mathrm{E}-03$ & $-1.66 \mathrm{E}-03 * * *$ & $5.84 \mathrm{E}-03$ & $-1.77 \mathrm{E}-03 * *$ & $01 \mathrm{E}-02$ & $-6.38 \mathrm{E}-04 * * *$ \\
\hline Percentage of tax revenue - most volatile & $-4.27 \mathrm{E}-02 *$ & $1.42 \mathrm{E}-03 *$ & $-3.73 \mathrm{E}-02 *$ & $5.95 \mathrm{E}-04 * *$ & $3.88 \mathrm{E}-02 *$ & $4.75 \mathrm{E}-04 *$ & $-3.95 \mathrm{E}-02 * *$ & $2.45 \mathrm{E}-04 *$ \\
\hline Percentage of expenditure - most volatile & $6.49 \mathrm{E}-02 * *$ & $5.12 \mathrm{E}-03$ & $8.42 \mathrm{E}-02 * * *$ & $1.64 \mathrm{E}-03 * *$ & $8.18 \mathrm{E}-02$ & $1.37 \mathrm{E}-03 *$ & $7.55 \mathrm{E}-02 * * *$ & $6.92 \mathrm{E}-04 * *$ \\
\hline Percentage of expenditure - least volatile & $-2.51 \mathrm{E}-03$ & $2.60 \mathrm{E}-03$ & $3.37 \mathrm{E}-03$ & 5.07E-04 & 3.88E-04 & 4.65E-04 & $6.10 \mathrm{E}-03$ & $2.30 \mathrm{E}-04$ \\
\hline Deviation from average per capita savings & $1.12 \mathrm{E}+00$ & $-1.40 \mathrm{E}-02$ & $1.21 \mathrm{E}+00$ & $-1.39 \mathrm{E}-02$ & $1.25 \mathrm{E}+00$ & $-9.67 \mathrm{E}-03$ & $8.61 \mathrm{E}-01$ & $-5.33 \mathrm{E}-03$ \\
\hline Tax effort & $-4.08 \mathrm{E}-05$ & $-8.43 \mathrm{E}-06$ & $1.79 \mathrm{E}-05$ & $-1.98 \mathrm{E}-06$ & $3.05 \mathrm{E}-05$ & $-1.87 \mathrm{E}-06$ & $-8.33 \mathrm{E}-05$ & $-7.42 \mathrm{E}-07$ \\
\hline Expenditure limitation & $6.65 \mathrm{E}-03$ & 4.92E-04 & $4.00 \mathrm{E}-03$ & $2.88 \mathrm{E}-04 *$ & $4.54 \mathrm{E}-03$ & $2.77 \mathrm{E}-04$ & $2.10 \mathrm{E}-03$ & $9.75 \mathrm{E}-05 *$ \\
\hline BBR stringency & $-3.06 \mathrm{E}-04$ & $-4.14 \mathrm{E}-05$ & $-1.52 \mathrm{E}-04$ & $-5.08 \mathrm{E}-06$ & $-1.30 \mathrm{E}-04$ & $-1.32 \mathrm{E}-06$ & $1.39 \mathrm{E}-04$ & $-1.09 \mathrm{E}-06$ \\
\hline Deviation from average per capita debt & $-7.03 \mathrm{E}-06$ & $-3.23 \mathrm{E}-07 *$ & $-6.63 \mathrm{E}-06$ & 5.32E-09 & $-7.02 \mathrm{E}-06$ & $-8.91 \mathrm{E}-09$ & $-5.53 \mathrm{E}-06$ & $1.86 \mathrm{E}-09$ \\
\hline Population density & 4.72E-06 & $-5.77 \mathrm{E}-09$ & $3.16 \mathrm{E}-06$ & $1.72 \mathrm{E}-07$ & 4.09E-06 & $1.66 \mathrm{E}-07$ & $4.50 \mathrm{E}-06$ & $8.93 \mathrm{E}-08 *$ \\
\hline Constitutional BSF & $-1.45 \mathrm{E}-03$ & $5.63 \mathrm{E}-03 * *$ & $-1.25 \mathrm{E}-03$ & $3.46 \mathrm{E}-03 * * *$ & $8.34 \mathrm{E}-04$ & $4.56 \mathrm{E}-03 * *$ & $9.49 \mathrm{E}-04$ & $3.18 \mathrm{E}-03 * *$ \\
\hline Deviation from average per capita net IG revenue & $1.09 \mathrm{E}-02$ & $1.49 \mathrm{E}-03 * *$ & $5.31 \mathrm{E}-03$ & $2.78 \mathrm{E}-04$ & $7.01 \mathrm{E}-03$ & $2.96 \mathrm{E}-04$ & $6.17 \mathrm{E}-03$ & $1.20 \mathrm{E}-04$ \\
\hline Log Likelihood & \multicolumn{2}{|c|}{-169.88079} & \multicolumn{2}{|c|}{-164.80986} & \multicolumn{2}{|c|}{-164.37042} & \multicolumn{2}{|c|}{-162.30124} \\
\hline
\end{tabular}

*** Significant at $1 \%, * *$ Significant at $5 \%, *$ Significant at $10 \%$

The dependent variable equals zero in years prior to BSF adoption, in the year of adoption it equals 1 if the adopted withdrawal requirement is lax and 2 if it is strict 


\section{References.}

- Advisory Commission on Intergovernmental Relations "State Fiscal Capacity and Effort" Washington, D C. ACIR, 1990.

- Advisory Commission on Intergovernmental Relations. "Fiscal Discipline in the Federal System: National Reform and the Experience of the States." Washington, D C. ACIR, 1987.

- Advisory Commission on Intergovernmental Relations "Measuring the Fiscal "Blood Pressure" of the States - 1964-1975" Washington, D C. ACIR, 1977.

- Advisory Commission on Intergovernmental Relations "Measuring the Fiscal Capacity and Effort of State and Local Areas" Washington, D C. ACIR, 1972.

- Alesina, A. and Bayoumi, T. "The Costs and Benefits of Fiscal Rules: Evidence from U.S. States. "NBER Working Paper 5614, 1996.

- Alt, J. and Lowry, R. "A Dynamic Model of State Budget Outcomes under Divided Partisan Government" The Journal of Politics, Vol. 62, No. 4, 2000.

- $\quad$ Amador, M. "Savings under Political Compromise" MIT Mimeo, 2003.

- Basham, P. "Assessing the Term Limits Experiment of California and Beyond" Cato Institute's Center for Representative Government, No. 143, 2001.

- Besley, T. and Case, A. "Political Institutions and Policy Choices: Empirical Evidence from the United States" Mimeo, 2001.

- Berry, W. Ringquist, E., Fording, and Hanson, R. "The Measurement and Stability of State Citizen Ideology" Forthcoming in State Politics and Policy Quarterly, 2006.

- Bohn, H. and Inman, R. "Balanced Budget Rules and Public Deficits: Evidence from the U.S. States. "National Bureau of Economic Research Working Paper, No. 5533 Cambridge, MA.

- Brecher, C., Richwerger, K. and Van Wagner, M. "An Approach to Measuring the Affordability of State Debt" Public Budgeting and Finance, 2003.

- Briffault, R. Balancing Acts: the Reality Behind State Balanced Budget Requirements. The Twentieth Century Fund Press, New York, 1996.

- Coffman, M. "A Rainy Day Fund for Colorado." Treasur-E-Notes, Vol. 3, Issue 40, 2002.

- Crain, W. and Muris, T. "Legislative Organization of Fiscal Policy" Journal of Law and Economics, Vol. 38, No. 2, 1995.

- Douglas, J. and Gaddie, R. "State Rainy Day Funds and Fiscal Crises: Rainy Day Funds and the 1990-1991 Recession Revisited." Public Budgeting and Finance, Spring 2002. 
- Drazen, A. Political Economy in Macroeconomics. Princeton University Press, Princeton, New Jersey, 2000.

- Elder, H. "Exploring the Tax Revolt: An Analysis of the Effect of State Tax and Expenditure Limitation Laws," Public Finance Quarterly, vol. 20, 1992.

- Gilligan, T. and Matsusaka, J. "Fiscal Policy, Legislature Size, and Political Parties: Evidence from State and Local Governments in the First Half of the 20th Century" National Tax Journal, Vol. 54. No. 1, 2001.

- Gilligan, T. and Matsusaka, J. "Structural Constraints on Partisan Bias under the Efficient Gerrymander."Vol. 100, No. 1, 1999.

- Gilligan, T. and Matsusaka, J. "Deviations from Constituent Interests: The Role of Legislative Structure and Political Parties in the States." Economic Inquiry, Vol. 33, No. 3, 1995.

- Gold, S. The Fiscal Crises of the States: Lessons for the Future. Washington, DC: Georgetown University Press, 1995.

- Gonzalez, C. and Paqueo, V. "Social Sector Expenditures and Rainy-Day Funds." World Bank Policy Research Working Paper 3131, 2003.

- Government Finance Officers Association. Recommended Budget Practices: A Framework for Improved State and Local Government Budgeting, GFOA 1998.

- Hagle, T. and Mitchell, G. "Goodness of Fit Measures for Probit and Logit" American Journal of Political Science, Vol. 36, 1992.

- Hausman, J. and McFadden, D. "Specification Tests for the Multinomial Logit Model" Econometrica, Vol. 52, No. 5, 1984.

- Heller, W. "Political Denials: The Policy Effect of Intercameral Partisan Differences in Bicameral Parliamentary Systems" Journal of Law, Economics, and Organization Vol. 17, 2001.

- Holcombe, R. and Sobel, R. Growth and Variability in State Tax Revenue: An Anatomy of State Fiscal Crises. Greenwood Press, Westport, 1997.

- Holtz-Eakin, D., Rosen H. and Tuller, S. "Intertemporal Analysis of State and Local Government Spending: Theory and Tests" Journal of Urban Economics 35, 1994.

- Hou. Y. "Fiscal Reserves and State Own-Source Expenditure in Downturn Years." Public Finance Review, Vol. 33, No. 1, 2005.

- Hou, Y. "Fiscal Reserves and Budgetary Reactions to Revenue Shocks;" University of Georgia, Mimeo, 2004. 
- Hou, Y. "Testing the Effects of Sub-National Counter-Cyclical Fiscal Policies: Budget Stabilization Funds, General Fund Surpluses, and State Total Own-Source Expenditures" Syracuse University, Mimeo, 2001.

- Joyce, P. "What's So Magical about Five Percent? A Nationwide Look at Factors that Influence the Optimal Size of State Rainy Day Funds." Public Budgeting and Finance, Summer 2001.

- Kirkland, K. "Creative Accounting and Short-Term Debt: State Responses to the Deficit Threat" National Tax Journal, Vol. 36, No. 3, 1983.

- Knight, B. and Levinson, A. "Rainy Day Funds and State Government Savings. "National Tax Journal, Vol. 52, No. 3, 1999.

- Knight, B. and Levinson, A. "Fiscal Institutions in U.S. States" University of Wisconsin, Mimeo, 1998.

- Krause, G. "Partisan and Ideological Sources of Fiscal Deficits in the United States" American Journal of Political Science, Vol. 44, No. 3, 2000.

- $\quad$ Kriz, K. "The Optimal Level of Local Government Fund Balances: A Simulation Approach" State Tax Notes, Vol. 27, No. 10, 2003.

- Lane, P. "The Cyclical Behaviour of Fiscal Policy: Evidence from the OECD" Journal of Public Economics, Vol. 87, No. 12, 2003.

- $\quad$ Lav, I. and Berube, A. "When It Rains It Pours: A look at the adequacy of State Rainy Day Funds and Budget Reserves."Center on Budget and Policy Priorities, 1999.

- $\quad$ Lazere, E. "Fixing D.C.'s Rainy Day Fund" D. C. Fiscal Policy Institute, 2003.

- Levinson, A. "Balanced Budgets and Business Cycles: Evidence from the States. "National Tax Journal Vol. 51 no. 4, 1998.

- Long, J. and Freese, J. Regression Models for Categorical Dependent Variables Using Stata, Stata Press, College Station, 2006.

- $\quad$ Lowry, R. and Alt, J. "A Visible Hand? Bond Markets, Political Parties, Balanced Budget Laws, and State Government Debt." Economics \& Politics 13, 2001.

- Lowry, R., Alt, J. and Ferree, K. "Fiscal Policy Outcomes and Electoral Accountability in American States" American Political Science Review, Vol. 92, No. 4, 1998.

- $\quad$ Lowry, R. and Alt, J. "Divided Governments, Fiscal Institutions, and Budget Deficits: Evidence from the States" American Political Science Review, Vol. 88, No. 4, Dec 1994. 
- Maddala, G. Limited-dependent and qualitative variables in econometrics_Cambridge, MA: Cambridge University Press, 1983.

- McCarty, N. "The Policy Consequences of Partisan Polarization in the United States" in the 2004 Seminar of Institutions and Positive Political Theory, Berkeley.

- McGranahan, L. "Unprepared for Boom or Bust: Understanding the Current State Fiscal Crisis" Economic Perspectives, Federal Bank of Chicago, 2002.

- Mody, A. and Fabrizio, S. "Can Budget Institutions Counteract Political Indiscipline?" IMF Working Papers, Washington DC, 2006.

- $\quad$ National Association of State Budget Officers. "Budgeting Amid Fiscal Uncertainty. Ensuring Budget Stability by Focusing on the Long Term. "NASBO, 2004.

- Navin, J. and Navin, L. "An Evaluation of Budget Stabilization Funds among Midwestern States" Growth and Change, Vol. 25, No. 4, 1994.

- $\quad$ New, M. "Limiting Government Through Direct Democracy. The case of state tax and expenditure limitations." Policy Analysis, N. 420, Cato Institute, 2001.

- $\quad$ New. M. "Where Term Limits lead to Tax Cuts", Cato Institute, 2001.

- $\quad$ Oates, W. "An Essay on Fiscal Federalism" Journal of Economic Literature, 1999.

- Oates, W. "On the Measurement of Congestion in the Provision of Local Public Goods" Journal of Urban Economics, Vol. 24, 1988.

- Pollock, R. and Suyderhoud, A. "The Role of Rainy Day Funds in Achieving Fiscal Stability." National Tax Journal 39(4), 1986.

- Poulson, B. "Grading the States' Tax and Expenditure Limits." Americans for Prosperity Foundation, June 2005.

- Poulson, B. "Creating a Budget Stabilization Fund for Colorado." Information for Colorado's Advisory Group Members, 2003.

- Poterba, J. "Budget Institutions and Fiscal Policy in the U.S. States." American Economic Review, Vol. 86, No. 2, 1996.

- Poterba, J. "Capital Budgets, Borrowing Rules and State Capital Spending" Journal of Public Economics 56, 1995.

- $\quad$ Poterba, J. "State Responses to Fiscal Crises: The Effects of Budgetary Institutions and Politics." Journal of Political Economy 102(4), 1994. 
- Poulson, B. "Grading the States' Tax and Expenditure Limits." Americans for Prosperity Foundation, 2005.

- Poulson, B. "Creating a Budget Stabilization Fund for Colorado." Information for Colorado's Advisory Group Members, 2003.

- Rodriguez-Tejedo, I. "Requirements and Limits on State Budgets" University of Maryland, Mimeo, 2006.

- Sawicky, M. "Altered States: How the Federal Government can Ease the States' Fiscal Crisis" Economic Policy Institute Issue Brief, No. 187, 2003.

- Small, K. and Hsiao, C. "Multinomial Logit Especification Tests" International Economic Review, Vol. 26, No. 3, 1985.

- $\quad$ Snell, R. "State Balanced Budget Requirements: Provisions and Practice." National Conference of State Legislatures. Article posted in April 1996, updated in March 2004.

- Sobel, R. "The Political Costs of Tax Increases and Expenditure Reductions: Evidence from State Legislative Turnover" Public Choice, Vol. 96, 1998.

- $\quad$ Sobel, R. and Holcombe, R. "The Impact of State Rainy Day Funds in Easing State Fiscal Crises During the 1990-1991 recession." Public Budgeting and Finance, Fall 1996.

- Tannenwald, R. "Methodology for Estimating Total Taxable Resources" U.S. Department of Treasury, 2002.

- $\quad$ Tannenwald, R. "Fiscal Disparity Among the States Revisited" State Tax Notes, Vol. 17, No. $15,1999$.

- Tannenwald, R. and Cowan, J. "Fiscal Capacity, Fiscal Need, and Fiscal Comfort among U.S. States" The Journal of Federalism, Vol. 27, No. 3, 1997.

- $\quad$ Tullock, G. "Problems of Majority Voting." Journal of Political Economy, Vol.67, No. 6, 1959.

- Velasco, A. "Debts And Deficits With Fragmented Fiscal Policymaking," Journal of Public Economics, Vol. 76, 2000.

- $\quad$ Von Hagen, J. "A note on the Empirical Evidence of Formal Fiscal Restrains" Journal of Public Economics 4(2), 1991.

- Wagner, G. and Sobel, R. "State Budget Stabilization Fund Adoption: Preparing for the Next Recession or Circumventing Fiscal Constraints?" Public Choice, Vol. 126, No. 1, 2006. 
- Wagner, G. and Elder, E. "The Role of Budget Stabilization Funds in Smoothing Government Expenditures over the Business Cycle." Public Finance Review 33(4), 2005.

- $\quad$ Wagner, G. "The Bond Market and Fiscal Institutions: Have Budget Stabilization Funds Reduced State Borrowing Costs?" National Tax Journal, Vol. 57, No. 4, 2004.

- Wagner, G. "Are State Budget Stabilization Funds Only the Illusion of Savings? Evidence from Stationary Panel Data." Quarterly Review of Economics and Finance, Vol. 43, No. 2, 2003.

- Wallis, J. "Constitutions, Corporations and Corruption: American States and Constitutional Change: 1842-52." The Journal of Economic History, Vol. 65, No. 1, 2005.

- Weingast, B., Shepsle, K. and Johnsen, C. "The political Economy of Benefits and Costs: A Neoclassical Approach to Distributive Politics" Journal of Political Economy, Vol. 3, No. 4, 1981.

- Williams, R. "Gologit2: Generalized Ordered Logit/ Partial Proportional Odds Models for Ordinal Dependent Variables." Stata Journal, Vol. 6, No. 1, 2006.

- Windmeijer, F. "Goodness of Fit Measures in Binary Choice Models" Econometrics Review, Vol.14, No. 1, 1995.

- Zahradnik, B. and Ribeiro, R. "Heavy Weather: Are State Rainy Day Funds Working?" Center on Policy and Budget Priorities, May 2003.

- Zahradnik, B. "Rainy Day Funds: Opportunities for Reform." Center on Budget and Policy Priorities, March 2005. 